Discussion Paper No. 1022

\title{
HOW CONSCIEOUS ARE YOU OF OTHERS? FURTHER EVIDENCE ON RELATIVE INCOME AND HAPPINESS
}

\author{
Sun youn Lee \\ Fumio Ohtake
}

March 2018

The Institute of Social and Economic Research Osaka University

6-1 Mihogaoka, Ibaraki, Osaka 567-0047, Japan 


\title{
How Conscious Are You of Others? Further Evidence on Relative Income and Happiness ${ }^{\dagger}$
}

\author{
Sun Youn Lee ${ }^{1}$, Fumio Ohtake ${ }^{2}$
}

Extant research has found that an individual's happiness is relative with respect to income, suggesting that it rises with own income and falls as the income of a reference group increases. Some recent studies emphasize that the effect of relative income is mediated by the extent to which people compare themselves with others (hereinafter, "relative consciousness"). Using the survey data of representative sample of Japan and the U.S., this paper extends the existing literature by providing a statistical evidence that underlines the importance of the intensity of relative consciousness in association with the perception of reference-group income in determining an individual's happiness and his/her decision in line with the maximization of the utility. First, we find people who are highly conscious of others' living standards are unhappier in Japan but happier in the U.S. This opposite effect between the two countries is also found to exist when the same estimation is conducted with panel data. Second, the positive relationship between relative consciousness and happiness found in the U.S. results from the perception of reference-group income: highly conscious people compare downward in the U.S. Lastly, we further examine the extent to which the integrated effect of relative consciousness and reference-group income is related to an individual's decision that could affect the degree of happiness. We discuss how our results can drive a wedge between choice behavior and happiness maximization and thus between happiness and decision utility.

Keywords: Happiness; relative income; relative consciousness; utility JEL Classification: D6, I31, J0

\footnotetext{
$\dagger$ This study is supported by a Grant-in-Aid for Scientific Research A [No. 26245041], provided by the Japan Society for the Promotion of Science to both authors, and the Joint Usage/Research Center provided by the Institute of Social and Economic Research at Osaka University to Fumio Ohtake. We are grateful for constructive comments and suggestions from the participants at the International Conference on "Work and Happiness," which was held from August 30 to September 1, 2017, in Seoul, South Korea. The authors are responsible for any errors in this article.

1 Corresponding Author: Faculty of International Studies, Meiji Gakuin University, 1518 Kamikurata-cho Totsuka-ku, Yokohama, Kanagawa 244-8539, Japan. Tel: 81-45-863-2241; E-mail: sylee@k.meijigakuin.ac.jp

2 Institute of Social and Economic Research, Osaka University, 6-1 Mihogaoka, Ibaraki, Osaka 567-0047, Japan. E-mail: ohtake@iser.osaka-u.ac.jp
} 


\section{Introduction}

The "Easterlin paradox" (Easterlin, 1974) of substantial real income growth and roughly constant happiness level has been widely researched and discussed by economists. Extant research has attempted to solve this puzzle by considering individuals' comparisons of own income with that of others in a relevant reference group (social comparison) as well as with the individual's own past income (adaptation). More specifically, the theory is that the main reasons why happiness does not change much, even with an increasing level of real income, are that proportional increases for all incomes in an economy would leave average happiness unaffected, and because people adapt to their changing income (Easterlin, 2001). In contrast, the bulk of evidence in the literature at the micro-level suggests that, despite the Easterlin paradox, within a single country, higher income significantly raises happiness. Clark et al. (2008) summarize how the relationship between income and happiness differs at the individual and aggregate levels. At the individual level, happiness increases steeply as income increases within a country at a given point in time, which suggests that high income earners are more likely to be happier than low income earners; this positive slope of the relationship is steep when the population of a country is poor. However, as the average income of the country gets higher, the slope flattens, which suggests that over time, the marginal utility of income by country at the aggregate level will be close to zero ${ }^{3}$.

Social comparison is one mechanism that explains nearly constant slope between income and happiness at the aggregate level. The status benefit of high income does not have an impact on country-level happiness because it is a zero-sum game. The gain in happiness that higherincome earners experience is accompanied by a corresponding loss in happiness of those in their comparison group. In other words, the benefit from status is relative. Under the hypothesis that happiness is a good proxy measure of "utility" (Hollander, 2001; Kahneman and Krueger, 2006) many studies have attempted to investigate how the size of income in actual and relative terms affects happiness. In addition to social comparison groups, some researchers have focused on how income adaptation explains the Easterlin paradox. Di Tella et al. (2007) find that the effect of an income increase after four years is reduced to $42 \%$ of the effect after one year. This suggests that the short-term effect of an income increase dissipates over time and that, in the long run, stable characteristics do not affect well-being. Some researchers have provided explicit evidence for a significant relationship between individuals' required income levels and own past income by

\footnotetext{
${ }^{3}$ Even in high-income countries, where the slope between income and happiness is close to zero, income and happiness are still positively correlated at a given time at the individual level (Clark et al., 2008).

4 A growing number of economists believe that happiness data obtained from self-reported survey questionnaires contain valuable information. Despite some concerns about measurement error and reference bias, it is believed that happiness data can enhance our understanding of individual behavior, and that happiness scores provide information about utility.
} 
using panel data, such as the German Socio-Economic Panel (SOEP) (Bartolini et al., 2013; Vendrik, 2013) and the British Household Panel Survey (BHPS) (Clark, 1999). In addition to using own past income as a reference point, "aspirations" are used in another study as an individual-level reference point. If aspirations rise in tandem with actual income, then the effect of income on happiness will be constant. Stutzer (2004) finds that, in Switzerland, individuals' income aspirations are increased by average community income, and that the increased aspirations negatively affect life satisfaction. McBride (2010) investigates the effect of aspirations by using the matching pennies game against various computer opponents. The author creates variations in aspirations by manipulating the probability distributions of heads and tails used by the computer and finds that, holding the payoff constant, as aspiration becomes higher, satisfaction becomes lower.

For a more accurate estimation of the regression of happiness on relative income, some recent papers (Clark and Senik, 2010; Goerke and Pannenberg, 2015) emphasize the importance of understanding the extent to which individuals compare themselves to others: happiness falls with the intensity of income comparisons. Mayraz et al. (2009) also report a negative average coefficient on the comparison intensity, using the sample of the 2008 pre-test module of the SOEP. Using an original web-based survey in Japan, Yamada and Sato (2013) conduct hypothetical discrete choice experiments in which they changed the definition of reference persons in hypothetical situation choice tasks (e.g., alternative combinations of hypothetical monthly income amounts provided to subjects, both for themselves and certain reference persons). Yamada and Sato (2013) note that a difference in intensity of relative utility is found depending on the degree of respondents' comparison: as expected, more jealous people experience a stronger negative effect of reference income on utility. With the same internet survey data, Clark et al. (2013) also find that increased comparison intensity leads to a decrease of satisfaction with income.

In addition to the comparison intensity, some recent studies imply that the features of subjects' reference groups are also important in the study of happiness and income comparisons (Hauret and Williams, 2017). More specifically, the relative utility can differ by comparison groups that determine "who compares to whom". Clark and Senik (2010) find that people who compare themselves to colleagues are happier than those who use other reference groups. In Mayraz et al. (2009), compared with other benchmarks, the effect size of relative income is found to be large when the comparison group is colleagues with the same profession. Yamada and Sato (2013) note that, in Japan ${ }^{5}$, those who compare themselves with neighbors have the strongest intensity of relative utility. Other comparison groups, such as family, friends, and colleagues, are consistently found to have a significant negative effect, albeit not as intense, for a given reference

\footnotetext{
5 An analysis of income comparisons based on Japanese data can also be found in de la Garza et al. (2012) and Oshio and Urakawa (2014).
} 
income. Senik (2009) summarizes the effects of heterogeneous comparison groups in different counties. For example, in countries where the degree of income mobility is high, such as the U.S., the comparison with a high income reference group is positive, while in countries where income mobility and uncertainty are low, such as Western Europe, the opposite result is observed. Godechot and Senik (2015) also provide a compelling evidence of the importance of defining the comparison group; the effect of reference income differs whether the reference group is either other workers in the same firm or similar workers in the region.

The wide range of these happiness papers assume that happiness scores provide valid information about utility. However, it has been argued that happiness may not be same as utility. Kimball and Willis (2006) argue that individuals' choices are not expected to maximize their happiness, which suggests there is more to life than happiness. Some argue that individuals are not good at foreseeing how much utility they will derive from future consumption (Loewenstein and Adler 1995; Frey and Stutzer 2014). By empirically testing an individual's commuting decisions, which involve trade-offs between extrinsic rewards (e.g., a more exclusive housing for the same price, or a higher salary) and intrinsic needs (e.g., time spent with family or friends), Frey and Stutzer (2014) find that people underestimate their utility with regard to intrinsic needs. Analyzing an individual's decisions in terms of both extrinsic and intrinsic needs helps us to understand some paradoxical observations of people who are not fully compensated for the decision which is expected to maximize their utility. Along this line, we should also allow for the fact that individuals might systematically mispredict utility (see Kahneman and Thaler, 2006 for more details) in line with the maximization of happiness.

Using a single dataset derived from the representative sample of Japan and the U.S., we attempt to address all these aspects of the effect of social comparison and aspiration, the effect of comparison intensity and comparison direction, and the relationship between happiness and utility. First, we examine the extent to which happiness rises with own income but falls with the income of a reference group, using three different measures for relative income, which involves both social comparison and aspiration theories. In the survey, respondents were asked to report the income of a comparison group and their own aspirational income. In addition, comparison with others' living standards was reported on a 1-5 scale, ranging from much lower to much higher. These three candidates for relative income within the same dataset allow us to more accurately estimate whether the utility is relative with respect to income. Furthermore, we also calculate the cell-mean measures of relative income for a comparison, using the same covariates that were collated by the same survey conducted in the same year in both Japan and the U.S. This enables us to understand the country-specific difference in relative utility in more depth.

Secondly, we focus on the extent to which individuals are conscious of others' living standards (hereafter, "relative consciousness") while considering the respondent's choice of 
comparison group. This is our fundamental interest in this work. The most related literature of our work is Goerke and Pannenberg (2015). They also examine the effect of income comparisons, with a particular focus on the comparison intensity and comparison direction. Consistent with other related literature, they find that the comparison intensity and higher-income reference group are both negatively correlated with subjective well-being; however, comparison intensity and perceived relative income do not interact. We attempt to empirically test the hypothesis that how the intensity of relative consciousness affects happiness depends on the income level of reference group. More specifically, we hypothesize that relative consciousness affects happiness differently between countries depending on whether most comparisons are upward or downward (Clark and Senik 2010). Upward comparisons would mean people intensively compare their income with others in higher-income reference groups. In this case, greater relative consciousness in association with upward comparisons will lead to a lowering of happiness. On the other hand, if people intensively compare themselves with lower-income reference groups, this comparison could positively affect happiness. Thirdly, after estimating the relationship between relative income and happiness, we examine whether people correctly predict the possible impact of relative income on an individual's decision which could affect their future happiness. We show that the decision could differ according to the degree of relative consciousness in combination with their perception of their relative income. We then discuss the link between happiness and individual decisions that are expected to maximize utility.

Accordingly, there are three main findings in our paper. First, our overall estimation results on income are consistent with previous studies. A regression of happiness on absolute income produces a positive estimated coefficient, as found in a wide range of the related microdata-based literature. As for the effect of relative income, we find that higher income in reference groups is associated with lower levels of self-reported happiness. This suggests that if others are better off, people feel less happy. When we use the level of own income needed to achieve a self-set level of welfare as a proxy for an individual's aspirations, we also find that, when aspirations are higher, people are less happy. The negative coefficient is also statistically significant for self-declared relative status in terms of living standard. These results suggest social comparison and aspiration both explain the effect of relative income. We obtained reasonably identical results from three different measures of relative income, which supports the stability of results based on perceived reference income. This is in line with Clark et al. (2017) who argue that the results obtained from happiness regressions with different measures of relative income are similar to those from hypothetical-choice regressions; this indicates that experienced and decision utility concur. It emphasizes the reliability of happiness regressions which are often criticized by the reverse causality between relative income and happiness.

Secondly, relative consciousness itself has a significant, albeit contradictory, effect on 
happiness in Japan and the U.S. It is negatively correlated with happiness in Japan, but positively correlated in the U.S. Contrary to the findings of previous studies, indicating that those who say that they compare more with others suffer more as relevant others' incomes rise, people in the U.S. feel happier if they are more conscious of others' living standards. It is interesting to explore why there exists an asymmetric effect of relative consciousness in association with relative income. Using an interaction term between relative consciousness and relative income, we predict that this difference could result from differences in the groups they are conscious of. We find that those who are highly conscious of others' living standards in the U.S. have a tendency to choose a low-income reference group. A statistically significant interactive effect is found for all three different measures of relative income. The results remain the same even after controlling for reference group choice. This implies that a relatively low-income reference group can be endogenously and actively chosen by people with a high relative consciousness. These downward comparisons through the choice of low-income reference groups enable highly conscious people in the U.S. to conceive themselves as having a relatively high status, which in turn is likely to make them feel happier.

Lastly, using a hypothetical question, we find that those who compare upward, which makes them unhappier, tend to prefer a living environment where they would be surrounded by a higherincome reference group. This means people could possibly make a choice that could make them less happy. This tendency is pronounced only among less conscious people. One possible interpretation is that less conscious people's preferences are not maximizing their happiness, which suggests that happiness might not act in the same way as "utility". This choice can also be explained by the possibility that people often mispredict their utility; then, their future expectation is not maximized to increase the degree of happiness. We then focus on highly conscious people who make the opposite choice by choosing lower-income reference neighbors. Why do highly conscious people, in particular those who currently perceive that their reference group contains higher-income earners, choose lower-income neighbors? This result is statistically significant in both countries, even when we use the sample restricted to those who chose neighborhood as the reference group. We discuss that being currently conscious of others might help them to "consciously" conceive the possibility that the relative income greatly matters for their happiness. Relative consciousness might then lead to make decisions that maximize their happiness.

Our overall results extend the existing literature by providing a statistical evidence that underlines the importance of the intensity of relative consciousness in association with the perception of reference-group income in determining an individual's happiness and his/her decision. While a limited number of studies examine how the comparison intensity mediates happiness, this work intends to make a contribution to better understand the effect of relative consciousness, which can be asymmetric by country, and the mechanism behind how it interacts 
with relative income in determining happiness and individual choice behavior, with a consideration of features of reference group. In order to obtain more reliable results, using panel data we also apply a fixed-effect model to examine the effect of relative consciousness and check the omitted variables bias using the method of Oster (2016). The remainder of this paper is structured as follows. Section 2 describes the data used for our analyses and empirical specifications. Estimation results are reported in Section 3. We then discuss the implications of the results and conclude in Section 4.

\section{Data and Method}

Our data source is the Osaka University Global CEO (GCEO) survey conducted in 2006 in Japan and the U.S. The GCOE survey started collecting data in 2004 from a representative group of Japanese and American households about socioeconomic status and a broad range of selfreported behaviors. Using the drop-off/pick-up method in February 2003, the first year of the survey covered a random sample drawn from 6,000 individuals selected by a double-stratified random-sampling method. It has been conducted annually since then, and new individuals were added to the following surveys using the same method. In the U.S., a panel survey has also been conducted annually, starting in January and February of 2005, using a mailing method with 4,979 individuals in the first group ${ }^{6}$. In this study, for the panel data analysis, we use the 2004 to 2006 data for Japan and the 2005 to 2006 data for the U.S. As the measures of relative income in addition to other control variables are included in survey year 2006 in both countries, the subsequent analyses are based on cross-section data of the 2006 survey. The survey data of 2006 are for 3,763 individuals in Japan and 3,120 individuals in the U.S. The control of demographic and labor-related variables, such as years of marriage, years of schooling, and type of employment reduced the sample sizes to 2,902 and 2,637 in Japan and the U.S., respectively.

The GCOE data provide us with a measure of happiness, a measure of income, and a rich set of control variables that the literature has identified as the main determinants of happiness, in particular, relative income, relative consciousness, and behavioral and labor-related variables. First, the data permit a direct estimate of the income of comparison groups and reference values for one's own aspirations. These questions enable us to construct three different measures of relative income, which are all used for comparison in the analyses in this study. Second, while identifying reference groups is often empirically difficult, this survey explicitly asked individuals about their reference groups by providing a list of options so that they could state to whom they compare themselves. Third, the survey has a question about relative consciousness, which is the main focus of our study. This question allows us to test our hypothesis that social comparison

\footnotetext{
${ }^{6}$ New individuals were added in the 2004, 2006, and 2009 surveys in Japan, and in the 2007, 2008, and 2009 surveys in the United States, using the same method as in the first survey year.
} 
effects on happiness can differ according to how much people are conscious of others. Fourth, it has a question about individual choices with regard to happiness, which allows us to discuss the relationship between happiness and utility. Finally, the survey includes a wide range of demographic and labor-related variables that have been reported to significantly affect happiness. Furthermore, these covariates were collated by the same survey conducted in the same year in Japan and the U.S.

\subsection{Happiness and Income in Absolute and Relative Terms}

This paper first focuses on the extent to which the degree of happiness is affected by one's own income, a widely researched topic in the field of happiness studies. Degree of happiness is measured on a scale of 1 to 10 by the following question: "Overall, to what degree are you currently feeling happy? Using a scale from $0-10$ where ' 10 ' is 'very happy' and ' 0 ' is 'very unhappy,' how do you rate your current level of happiness?" As shown in Table 1 and 2, overall, American respondents are happier than Japanese respondents. About 55\% of American respondents rated their current level of happiness at 8 or more, whereas the proportion of respondents in Japan who rated their happiness at 8 or more is only $28 \%$, about half of the level for Americans. In both countries, those who rated their happiness as 4 or less, indicating overall unhappiness, constitute about $12 \%$ of the sample.

We use the household income, which is measured by using annual earned household income before taxes including bonuses received by any member of the household for 2005, as a proxy for absolute income in the happiness regressions; a number of household is included in the model as a control variable. As for the question regarding an individual choice in (see Eq. (4) in Section 3), it explicitly compares own income with others for a choice of living environment. Thus, we use own annual income before taxes including bonuses ${ }^{7}$ as absolute income. Respondents report their household and own income using a list of 11 categories, where category 1 refers to an annual figure of below \$10,000 (1 million Japanese Yen (JPY) for the Japanese survey) and category 11 corresponds to an annual income of over $\$ 200,000$ (2 million JPY). Income is calculated as the mid-point of each of the nine intermediate categories; values of 5 and 25 million JPY are assigned to two extreme categories. To see the correlation between happiness and absolute income, we first categorize the household income data into three groups using the $25 \%$ and $75 \%$ percentile thresholds as separators. The calculated the percentage of each scale of happiness by income group is shown in Table 2. This indicates the positive relationship between happiness and income in both countries. The high-income group rates their degree of happiness as higher than the low-

\footnotetext{
${ }^{7}$ We find that the overall results using different types of income data do not differ significantly. However, the explanatory power of each model is stronger when household income is used for happiness equation (Eqs. (1) to (3)) and own income for individual choice equation (Eq. (4)).
} 
and middle-income groups. This is clearly observed from level 7 in both countries. More people in higher income group give an answer of scale of 7 and more.

For relative income, we constructed three variables, using self-declared reference-group income. First, we use the question: "How does your standard of living compare with people around you?" measured on a 5-point scale (hereafter, living standard comparison). More than half of people in Japan (57.3\%) and the U.S. (60.4\%) think that their own standard of living is about the same as other people around them. There are more Americans (12.2\%) than Japanese (8.0\%) who think that the living standards of other people are at least somewhat lower than their own, whereas more Japanese (34.7\%) than Americans (27.4\%) think the living standards of other people are comparatively higher. Second, the survey asks respondents to compare their own household income with the household income of other people: "How much household income is common for people around you?" (hereafter, social comparison income). This is measured using 12 income categories ranging from less than $\$ 10,000$ to more than $\$ 200,000$. Same as for one's own household income, reference income is calculated as the mid-point of each of the intermediate categories. Last, we also consider aspirational income using the following question: "How much income do you think is natural for your household?" (hereafter aspiration comparison income). This is also measured by the mid-point of each of the intermediate categories. As social comparison income and aspirational comparison income are measured in the same units as own household income, we can directly compare the estimated coefficients on income in both absolute and relative terms. Table 1 reports the mean value of each measure of relative income in logarithmic form.

These three types of relative income measure are based on the perceptions of respondents about others' living standard, other's reference income, and one's aspirational income. It is arguably of use to have information on what individuals perceive others earn. To empirically test the effect of income in relative terms, some previous studies (Ferrer-i-Carbonell, 2005; Knight and Song, 2009) compute or estimate reference group income. Clark and Oswald (1996) estimate wage equations, with controls for individual characteristics, and then compute the predicted income of the reference group. They compute averages within groups defined by several individual characteristics matched in from an external source. Other studies use computations of average income by state (Blanchflower and Oswald, 2004), by local area (Luttmer, 2005), by family and friends (Senik, 2009), by colleagues (Brown et al., 2008), and by neighbors (Luttmer, 2005; Knight et al., 2009). Following these previous studies, to provide a comparison for results based on respondents' perceptions, we calculate the expected mean income of comparable others predicted from a standard form of the Mincer earnings equation, conditional on age dummies, gender, education categories (and labor-related variables for a comparison).

Self-declared comparison income can largely depend on the particular comparison group that 
is endogenously chosen for comparison. Our data include information about which comparison group respondents have in their mind when they answered the question about their relative status in terms of living standard. Without this comparison group information, we can only obtain an average effect of relative income estimated over the whole sample, with the reference group being considered to be same for all respondents. The most frequent reference group in both countries is neighbors (49.74\% in Japan and 51.04\% in the U.S.) $)^{8}$. The distributions of comparison groups are very similar in Japan and the U.S. (see Table B for details). Approximately 10\% compare themselves with friends, colleagues, and family members. Additionally, $12 \%$ and $18 \%$ of people in Japan and the U.S., respectively, considered average people in their own country or the world as their comparison group. We also report the mean values of relative consciousness and relative income, which is calculated by $\ln \left(Y_{R_{i}}^{j} / Y_{i}\right) ; Y_{R_{i}}^{j}$ is reference-group income and $Y_{i}$ is own income. In both countries, comparison group who have the strongest intensity of relative utility is friends and acquaintances. To distinguish the effect of a choice of comparison groups, we use this information in our estimation either by including the group as a dummy variable (representing 12 comparison groups) in the model or by restricting the sample into a certain comparison group.

\subsection{Relative Consciousness}

Our main focus is the effect of people's relative consciousness. It has been found in previous research that those who say they compare more tend to feel less happy (Mayraz et al., 2009; Clark and Senik, 2010; Coerke and Pannenberg, 2015). This indicates that the intensity of income comparison on its own negatively affects happiness. Clark et al. (2013) report that it mediates the effect of relative income on happiness. People feel less happy if their income is a relatively low compared with their reference group and this negative effect is aggravated for those who state they compare their incomes more. We investigate the extent to which the relative consciousness of other people's standard of living affects happiness on its own and in association with relative income. For this, we construct an variable named "relative consciousness" using the following statement with agreement measured on a 5-point scale: "I am conscious of other people's standard of living."

Column 1 of Panel A in Table 3 shows the overall distribution of the intensity of relative consciousness. For an easier comparison, we first recoded the "living standard comparison" variable into three categories: (i) lower (sum of much lower and somewhat lower); (ii) same as

\footnotetext{
${ }^{8}$ In Yamada and Sato (2013), who use a Japanese sample, the reference group chosen the most often is friends $(42 \%)$, followed by work colleagues $(20 \%)$, while about $25 \%$ of respondents say they do not make such income comparisons. The difference might arise from the difference in the survey question. Yamada and Sato (2013) ask for the comparison group in relation to "income", whereas in our data the comparison is in relation to "living standards" of people around respondents. In addition, the choice options of perceived reference group differ between the surveys; in particular, we do not allow for the choice of not comparing with others.
} 
mine; (iii) higher (sum of much higher and somewhat higher). While only $23.2 \%$ of Japanese respondents give an answer of four or five on a 1-5 scale, about $60 \%$ of people in the U.S. do. This shows that contradictory trends exist in Japan and the U.S.: overall, Japanese people do not much care about other people's living standards, while Americans care about the relative level of other people's living standards ${ }^{9}$. Column 2 of Table 3 indicates the mean values of respondents' own household income sorted by the degree of relative consciousness of others' living standards. Columns 3 to 5 report the mean values of the relative income measures. As relative consciousness increases, one's own income and relative income increase in Japan. This suggests that those who say they are more conscious of others' living standards perceive that their reference group income and their own aspirational income are higher than their own income. In other words, those who are more conscious of others feel a large gap in income between their own and reference group. This tendency is not clearly observed in the U.S.

The positive correlation between income in both absolute and relative terms and relative consciousness in Japan is more explicitly observed in the Panel B of Table 3. It reports part of the results of the regression of relative consciousness on absolute and relative income in addition to demographic and labor-related variables. In Japan, as mean values sorted by relative consciousness indicate, we can observe the positive, statistically significant correlation between income in both absolute and relative terms and relative consciousness. Those who report a larger gap in social comparison income and aspirational comparison income are more likely to feel conscious of others in Japan. It can be reversely explained in that more conscious people feel a stronger intensity of relative utility.

\subsection{Empirical Specifications}

Under the hypothesis that happiness is a reliable proxy measure of utility, Clark et al. (2008) explained how two types of relative or comparison income terms (social comparison and adaptation) affect utility using the individual utility function $U_{t}=U\left(u_{1}\left(Y_{t}\right), u_{2}\left(Y_{t} \mid Y_{t}^{*}\right), u_{3}(T-\right.$ $\left.l_{t}, Z_{1 t}\right)$ ), where $Y_{t}$ is the vector of incomes $y_{t}$ from $\mathrm{t}=0$ to $\mathrm{t}$ and $u_{1}($.) can be thought of as utility from consumption $\left(\mathrm{u}_{1}^{\prime}>0, \mathrm{u}_{1}^{\prime \prime}<0\right)$. In a one-period model without savings, $U_{1}\left(Y_{t}\right)=$ $u_{1}\left(y_{t}\right)=u_{1}\left(c_{t}\right)$. Also, the difference $T-l_{t}$ considers the influence of leisure (with $l_{t}$ indicating hours at work) and $Z_{1 t}$ denotes a vector of other socio-economic and demographic

\footnotetext{
9 Our data indicate that compared with respondents in the U.S., Japanese respondents are less conscious of others' living standards. Comparatively, Clark et al. (2013) compare the comparison intensity between Japanese and Europeans. The percentage of Japanese who do not compare their income with others (25\%) is notably lower than that of Europeans (36\%). They note that the Japanese are more comparison conscious than are Europeans. This result is not directly comparable with our results for Japan, for the following two reasons. First, the surveys from which our data are derived do not allow for the choice of not comparing with others which would mean that respondents do not have a comparison group. Second, Clark et al. (2013) use a more direct question to measure the comparison intensity in relation to "income": "How much are you concerned, anxious or envious about other people's incomes?"
} 
variables. To empirically apply this utility function, the equation can be written as $U_{t}=$ $\beta_{1} \ln \left(y_{t}\right)+\beta_{2} \ln \left(y_{t} / y_{t}^{*}\right)+Z_{t}^{\prime} \gamma$, where $y_{t}^{*}$ is the "reference group income" and the ratio $y_{t} / y_{t}^{*}$ is called "relative" income. The reference point can either be a comparison group, such as family, neighborhood, region or country, or it can be own past income. When reference points are determined externally, we can interpret $u_{2}\left(Y_{t} \mid Y_{t}^{*}\right)$, where $\mathrm{u}_{2}^{\prime}>0$, $\mathrm{u}_{2}^{\prime \prime}<0$, as the "status return" from income or the positional aspect of income. Based on related literature, we set up four economic models to investigate the relation between happiness and income comparison. All equations are estimated by using Ordinary Least Squares (OLS) for an easier comparison of coefficients. The results obtained from OLS do not differ markedly from those from other estimation methods, such as ordered logit or ordered probit (for a comparison, see Table $\mathrm{A}^{10}$ ), as found by Luttmer (2005) and Clark et al. (2017). We start from the baseline empirical specification to investigate the determinants of happiness as follows:

$$
\mathrm{h}_{i}=\alpha+\beta_{i} \ln Y_{i}+\delta_{j} \ln Y_{R_{i}}^{j}+X_{i}^{\prime} \gamma+\varepsilon_{i}
$$

In Eq. (1), $\mathrm{h}_{i}$ is a measure of happiness reported by respondent $i$, and $Y_{i}$ is respondent $i$ 's annual household income. With the control of own household income $\left(Y_{i}\right)$, we include the relative income $Y_{R_{i}}^{j}{ }_{11}$ which indicates income of reference group $j$ which is self-reported by respondent i. $Y_{i}$ and $Y_{R_{i}}^{j}$ (social comparison income and aspiration comparison income) are entered in log form in the regression analysis. In Eq. (1) we focus on the size and directions of the coefficient $\delta$, which reports the effects of relative income. Clark and Senik (2010) explain it can be either positive or negative. People are less happy when the reference group does better. In contrast, reference group income contains information about the individual's own future prospects, which produces the reverse effect. $X_{i}$ is a vector of control variables that contain demographic variables, behavioral variables (e.g., health condition and degree of religious devotion) and labor-related variables (e.g., employment type, unemployment experiences, etc.), which have been found to be important determinants for happiness in a wide range of related literature. Another important control variable in our work is a dummy variable that indicates the reference group against which

10 Table A compares the results obtained by Ordered logit and OLS; we do not see a significant difference by estimation methods. We also report the results by gender; overall results that particularly involve our main control variables are reasonably similar for men and women in our work. We only document the results based on the whole sample for main estimations throughout the text.

${ }^{11}$ We use other three measures as a proxy for the reference income of $Y_{R_{i}}^{j}$. First, we calculated the relative income using a standard from of the Mincer earnings equation to obtain a predicted wage. Secondly, following the utility function introduced in Clark et al. (2008), we calculated the relative income as $\ln \left(Y_{R_{i}}^{j} / Y_{i}\right)$. Thirdly, for a more explicit comparison, we also estimated Eq. (1) with $Y_{R_{i}}^{j}-Y_{i}$ as the relative income, while controlling for one's own income. As for the second and third measures, positive values indicate that the respondent views others' household income and aspirational income as higher than their own. In other words, they have a higher-income reference group. We do not find any significant difference between the effects of relative income measured by log or not. For a comparison with our main result, we report the result obtained when the relative income is measured by $Y_{R_{i}}^{j}-Y_{i}$ in Table C. 
a respondent compares himself or herself: for example, neighborhood, friends, family members, colleagues, or average people (see Table B for details).

In addition to the effect of one's own actual income and relative income, we consider the extent to which a respondent is conscious of others' living standards as follows:

$$
\mathrm{h}_{i}=\alpha+\beta_{i} \ln Y_{i}+\delta_{j} \ln Y_{R_{i}}^{j}+\varphi_{i} R . C_{i}+X_{i}^{\prime} \gamma+\varepsilon_{i}
$$

The term $R . C_{i}$ denotes the degree of relative consciousness measured on a five-point scale ( 5 = highest). This captures an effect that can be described as comparison intensity based on envy, jealousy or self-enhancing motivation. To find the partial effect of relative consciousness, we first included $R . C_{i}$ on its own, as in Eq. (2). As for relative consciousness, the answer was also recorded in 2004 in Japan and in 2005 in both Japan and the U.S. We observe the change in relative consciousness over time among some respondents, which possibly affects the change in their happiness. Thus, we examine within-subject variability using a fixed effects model: $\mathrm{h}_{i t}=$ $\alpha+\beta \log Y_{i t}+\varphi R . C_{i t}+X_{i t}^{\prime} \gamma+\varepsilon_{i t}$. R. $C_{i t}$ denotes changes of relative consciousness within individuals, which we predict causes the individual's happiness to be changed over time. In this equation, time-invariant variables such as gender and educational attainment are excluded (see Table 6 for results).

Our main focus is to examine whether relative consciousness affects happiness differently according to a choice of reference income group. We thus include an interaction term for relative income and relative consciousness; the effect of which can be found in the coefficient $\theta$ in Eq. (3). If income comparisons are made downward among highly conscious people by comparing with a low-income reference group, $\theta$ will be positive; by contrast, if income comparisons are rather upward, it will be negative. We hypothesize that in the U.S., the positive effect of comparison with a low income reference group would be strengthened among people who are highly conscious of others; in this case, the coefficient $\theta$ takes a positive value (see Table 7 for results).

$$
\mathrm{h}_{i}=\alpha+\beta_{i} \ln Y_{i}+\delta_{j} \ln Y_{R_{i}}^{L I R G}+\varphi_{i} R . C_{i}^{H}+\theta_{i}\left(Y_{R_{i}}^{L I R G} \times R . C_{i}^{H}\right)+X_{i}^{\prime} \gamma+\varepsilon_{i}
$$

To investigate the interactive effect that occurs when highly conscious people compare themselves with a low income reference group and to more explicitly interpret the result, instead of including the consecutive variables denoted by $Y_{R_{i}}^{j}$ and $R . C_{i}$ in Eq. (2), we converted them into binary indicators. $Y_{R_{i}}^{L I R G}$ indicates others' income is lower than one's own $\left(Y_{R_{i}}^{j} \leq Y_{i}\right)$; as for R. $C_{i}^{H}$, it equals 1 if respondents are highly conscious of others. Comparing $\varphi$ and $\theta$, we can see whether the effect of relative consciousness differs depending on the income level of comparison group ${ }^{12}$.

${ }^{12}$ For a comparison, we estimate Eq. (2) with the same binary indicators, $Y_{R_{i}}^{L I R G}$ and $R . C_{i}^{H}$, which are used for Eq. (3). The overall results are reasonably similar to the results obtained from ordinal variables in Eq. (2). 
To further examine the effect of relative consciousness, we set up a model (4) where the dependent variable, $\mathrm{D}_{i}$, is a hypothetical decision about where to live. For this, we use the following question: "In which kind of town do you prefer to live: where the people are richer than you or the people are poorer than you? (Assume these two towns have the same degree of safety and convenience)." The responses are grouped as an ordinal variable on a five-point scale in which 5 indicates that other people are much richer than oneself while 1 indicates that other people are much poorer than oneself. Thus, a bigger answer indicates that respondents want to live with a higher-income reference group. We start with the Eq. (4) without the interaction term $\theta$. In this case, if $\delta$ is statistically significant and positive, it indicates that respondents with a higher reference income group tend to prefer a town in which neighbors come from a higher-income reference group. If we find that having a higher-income reference group makes people less happy in the estimation of Eq. (2), the positive coefficient of $\delta$ suggests that they might make a choice which could make them less happy.

$$
\mathrm{D}_{i}=\alpha+\beta_{i} \ln Y_{i}+\delta_{j} \ln Y_{R_{i}}^{H I R G}+\varphi_{i} R \cdot C_{i}^{H}+\theta_{i}\left(Y_{R_{i}}^{H I R G} \times R \cdot C_{i}^{H}\right)+X_{i}^{\prime} \gamma+\varepsilon_{i}
$$

Our fundamental interest is the effect of degree of relative consciousness in association with relative income. To more explicitly interpret the result, as we did in Eq. (3), we use binary indicators $Y_{R_{i}}^{H I R G}$ and R. $C_{i}^{H}$ in the estimation of Eq. (4). $Y_{R_{i}}^{H I R G}$ indicates others' income is higher than one's own $\left(Y_{R_{i}}^{j}>Y_{i}\right)$; as for $R . C_{i}^{H}$, it equals 1 if respondents are highly conscious of others $^{13}$. By using these two binary indicators, we can examine the interactive effect of relative consciousness and relative income. We focus on the sign and direction of $\theta$ with the hypothesis that a higher relative consciousness helps respondents "consciously" prefer a choice of a lowincome reference group, which in turn could make them happy. If it holds true, $\theta$ should be negative and statistically significant.

\section{Results}

\subsection{Effects of Income in Actual and Relative terms}

We start from the basic estimation of Eq. (1) to investigate the effect of income on level of happiness, controlling for individual demographic and labor-related variables. Column 1 of Table 3 indicates that one's own household income is significantly correlated with happiness, as found in a wide range of previous studies ${ }^{14}$. As for other socio-economic variables, we have obtained

\footnotetext{
13 In Eq. (3), a binary indicator of lower-income reference group is used as a proxy for relative income, while in Eq. (4), a binary indicator of higher-income reference group is used. Despite some possible confusions, we set up the models in this way to test our hypotheses; the effect of lower-income reference group in association with relative consciousness on an individual's happiness; the paradoxical effect of higher-income reference group in association with relative consciousness on an individual's choice.

14 For own income, we also use subjective measurement which indicates one's own living standard measured on an eleven-point scale ( 0 is lowest and 10 is highest). The results are overall same as those for an objective measure of annual household income.
} 
results that are highly consistent with those of previous studies (for a review, see Dolan et al., 2008; for the estimation results, see Table A). Household income in absolute term, is positively correlated with happiness in both countries, everything else being equal. To briefly summarize the results of social-economic variables, in Japan, women, married people, non-participants in the labor force, those with a child, and persons with higher educational attainment, fewer family members, good health, and higher religious devotion are happier. In the U.S., people who are younger or older (i.e., not in the middle; the age effect has a U-shape ${ }^{15}$ ), married, not labor force participants, have fewer family members, have good health and higher religious devotion are happier. In both countries, past experience of unemployment is negatively and statistically significantly correlated with happiness after controlling for labor-related variables. A wide range of previous research has identified clear, positive relationships of happiness with income, marriage, job status, health, and religion (Kahneman et al. 1999; Layard, 2005). The implicit values of employment and marriage in Australia are found to be worth about twice mean yearly income (Carroll et al., 2009). Having children and additional education are found to only slightly affect utility since these have strong choice elements (Clark et al., 2008). Overall, our results are consistent with previous results for socio-economic and labor-related factors.

Columns (2) to (4) of Table 3 report the effect of relative income, which was measured using three variables, while controlling for own income. All three measures of relative income are negatively and statistically significantly correlated with happiness. One exception is aspiration comparison income in the U.S. which is not significant. This might be because the variation in this measure is very small in the U.S.: many respondents' actual income and aspirational income do not differ much. The first measure of relative income, living standard comparison, suggests that if others' living standards are perceived to be higher than one's own living standard, people are unhappier, in both Japan and the U.S. In addition, the negative coefficients of social comparison income and aspiration comparison income indicate that when there is a larger gap in income between the reference group and own income, or between one's own aspiration income and actual income, the degree of happiness decreases. In summary, an increase in household income is associated with an increase of happiness while an increase of social comparison income and aspiration comparison income decreases happiness in both countries ${ }^{16}$. The sign of the coefficients of relative income can be positive or negative. Clark and Senik (2010) explain this

${ }^{15}$ For a more detailed discussion of the U-Shaped relationship between age and happiness, see Easterlin (2006).

${ }^{16}$ For a more explicit interpretation of the coefficients regarding relative income, we created an indicator of $Y_{R_{i}}^{j}-Y_{i}$ as a proxy for relative income. A positive value indicates that household income of the comparison group or one's own aspirational income is higher than actual household income. The unit is 10,000 USD ( 1 million JPY). The coefficients indicate that an income difference of approximately 1 million JPY of annual household income decreases happiness by 0.46 unit in Japan; in the U.S., 0.34 unit of decrease in happiness results from a relative income difference of ten thousand USD. 
ambiguous effect of relative income on happiness using two effects. On the one hand, people are less happy when the reference group does better, which is referred to as the standard "envy" effect. On the other hand, reference group income contains information about the individual's own future prospects, which produces the reverse effect and is referred to as the ambition or "information" effect; it is also known as the tunnel effect (Hirschman-Rothschild comparison, 1973). In our work, we find negative coefficients, implying that the envy effect dominates: people feel less happy if others' incomes or their own aspiration income are higher than their current income.

For a comparison, we calculated household income predicted from the Mincer equation with age dummies, education categorization, gender. It is generally found that results are highly sensitive to specification, and in some cases the estimated coefficient is close to zero, or even has the opposite sign (Mayraz et al., 2009) ${ }^{17}$. In our analysis, the estimated coefficients in both Japan and the U.S. are insignificant and, for the case of Japan, the sign is nominally opposite. This contrasts with the similar results that are found for all three measures of self-reported relative income in both Japan and the U.S. This suggests that the effect of income comparisons might be captured better by a measure of self-reported relative income. de la Garza et al. (2012) argue that the estimated absolute and relative income effects are not salient, when the happiness regressions are based on reference income defined using Mincer-predicted wages. They point out the difficulty of finding valid exclusion restrictions as the possible reason for the unstable estimation results. Clark et al. (2013) also compare self-reported comparison income with cell means using both internal and external data based on age, education, gender and labor force status. The results between self-reported and cell-means reference income differ by how the cell-means are defined. They note that self-reported measures are far more salient in providing comparison-income information $^{18}$. In line with Clark et al. (2013), it can be interpreted that simple questions on comparison income might better capture the actual reference group; or, a more important determinant for happiness may not be what comparable others actually earn, but rather what people believe others earn. Even if the reference group who is found to have similar demographic and labor-related backgrounds from the Mincer equation earns much more, it may not affect happiness if people do not compare themselves to this reference group.

17 For a comparison, residence dummies and/or labor-related variables are additionally included to calculate the predicted value of income. However, the estimated absolute and relative income effects are highly unstable depending on specifications.

18 In contrast to Clark et al. (2013), Clark et al. (2017; Table 3), using the same dataset, report the similar results between cell-mean measures matched within and outside the dataset and self-declared reference income. This might be due to different empirical specifications. In their more recent work, the happiness regressions do not control for the influences of other demographic and socio-economic variables, such as gender, education, marital status, region, occupation. It can be also because of differently defined cellmeans. 


\subsection{Relative Consciousness and Relative Income}

We investigate the specific effect of relative consciousness on happiness using Eq. (2), in which individual demographic and labor-related variables are held constant (see Table 5). We find contradictory results for Japan and the U.S. in terms of the effect of relative consciousness: it is negatively correlated with happiness in Japan, whereas there is a positive correlated in the U.S. As the first row of Table 5 indicates, relative consciousness is significantly correlated with happiness even when controlling for own actual income and relative income in addition to demographic and labor-related variables. Column (1) shows that happiness increases by 0.32 and 0.26 points to a one-standard-deviation of ( $\log$ ) net household income. Comparatively, respondents who perceive relative consciousness intensively exhibit a degree of happiness that is lower by 0.26 and 0.1 points to a one-standard-deviation of relative consciousness reported on a 1-5 scale in Japan and the U.S., respectively. The effect of relative consciousness is not largely different from that of absolute income if we consider happiness is ranged on a $0-10$ scale $^{19}$. This suggests the importance of relative consciousness as a determinant for happiness.

Column (2) reports the coefficients of relative consciousness when they are included as a dummy for all levels. When the base is five which indicates the largest degree of relative consciousness, we find that in Japan, lower levels of relative consciousness are positively correlated with happiness, while in the U.S., lower levels of relative consciousness are negatively associated with happiness. With an inclusion of relative consciousness, we no longer observe a significant correlation between social comparison income and happiness in Japan. The effect is reference-group income is captured by the degree of relative consciousness in Japan. Other coefficients of relative income are reduced in size, which suggests that the effect of income comparisons is mediated by relative consciousness.

Relative consciousness is a subjective measure, which can be correlated with unobserved variables. It might then capture some unknown effect. Using the panel data, we examine the effect of within-subject variability in relative consciousness on happiness. The opposite results of relative consciousness for the countries in an analysis using panel data are also clearly seen. Column (2) of Table 6 under each country indicates the results of a fixed-effect model. Column (4) shows the results of the fixed effect model when the panel data is balanced. The coefficients of relative consciousness in Japan in Columns (1) and (3) are all negative and significant. This suggests that Japanese people who become more conscious of other people's living standards feel

\footnotetext{
19 The effect of relative consciousness is not largely different from that of relative income; if respondents believe that their perceived reference group earns more than themselves, it lowers happiness in both countries by 0.33 and 0.19 in Japan and the U.S., respectively (Column (3)). The effects of both absolute income and relative consciousness in Japan/the U.S., when relative income is controlled for, become $0.24 / 0.22$ points and $0.25 / 0.10$ points, respectively, which are smaller but not much different from those obtained when relative income is not controlled for.
} 
less happy; the increase in relative consciousness from 2004 to 2006 decreases the degree of happiness in the same analyzed years. This is consistent when we only use the sample of people who answered in every year (see the result of balanced data in Column (4)). In contrast, the same coefficients in the U.S. are positive and statistically significant. This means that within-subject variability in relative consciousness is significantly associated with the increase in happiness in the U.S. Becoming highly conscious in the U.S. leads to a higher degree of happiness. These opposite effects found in Japan and the U.S. remain significant even when including the three relative income variables as controls ${ }^{20}$. These results assure that relative consciousness matters for happiness. It should be however noted that the panel estimation here does not completely solve the possible problem of reverse causality.

We further investigate the possible mechanism behind the opposite effect of relative consciousness in Japan and the U.S. We hypothesize that the extent to which people are conscious of others' living standards is associated with their perception on their relative status, which could affect happiness in a different way. For example, if highly conscious people compare themselves to a higher-income reference group, the intense relative consciousness would decrease the happiness, which has been found in some previous studies (Clark and Senik, 2010; Mayraz et al. 2009). However, highly conscious people intensively compare downward, the effect of relative consciousness can be opposite. We first focus on size and direction of coefficients $\varphi$ and $\theta$ in Eq. (3). Note that the coefficient of $\varphi$ is a binary indicator of high relative consciousness, while the coefficient of $\theta$ is interaction between binary indicators of high relative consciousness and a low-income reference group. Thus, the positive coefficient of interaction $(\theta)$ indicates that being highly conscious of others increases happiness when the income level of reference group is lower.

As Column (4) of Table 7 indicates, in the U.S. the interaction $(\theta)$ is positive and statistically significant. This suggests that highly conscious people report a higher degree of happiness when they compare themselves with low-income groups. The positive and statistically significant coefficients of the interaction term $(\theta)$ are consistently found for all three different measures of relative income, as indicated in Columns (4) to (6) of Table 7. This indicates that in the U.S., the reason why highly conscious people are happier is because they see their relative status higher than others through downward comparisons. Comparatively, the coefficient of $\varphi$ reports the happiness of highly conscious people with high income reference group. The negative sign suggests that when those who are highly conscious of others compare themselves with high income reference group, they may be less happy. However, it is not statistically significant. These results suggest that the integrated effect of relative consciousness is positive in the U.S. due to a

\footnotetext{
${ }^{20}$ We report the random effect results in Column (2) for comparison, although the Hauseman test shows that the fixed-effect is preferred. Relative income (measured only in 2006) are only included into the random effect model.
} 
stronger positive effect that comes from the comparison with low income reference group.

In contrast, we find that in Japan, the coefficient of the interaction $(\theta)$ is not statistically significant. It suggests that even though those who are highly conscious of others report a lower happiness, it is not associated with the income level of comparison group. In other words, relative consciousness and relative income are both negatively, but separately, associated with happiness in Japan. What the positive coefficient of $\delta$ in addition to $\theta$ indicates is that in both countries, comparison with a low-income reference group on average increases the happiness.

\subsection{Individual Choice and Relative Factors}

Thus far we have focused on the influence of relative variables on current happiness. We attempt to investigate the link between happiness and an individual decision in line with the maximization of utility using Eq. (4). A dependent variable measures the life choices individuals would make about residing in a town where, when compared to the respondent's own circumstances, living standards are generally higher, about the same, or lower. A higher value of individual choice for a town indicates that a respondent would choose a town in which the reference group of neighbors would have a higher income than himself or herself. In this section, we mainly report the estimation results and will then proceed to discuss their implications in Section 4.

Table 8 reports a positive and statistically significant correlation between individual choice and relative income in both Japan and the U.S. This suggests that those who respond that their reference group has a higher living standard and higher household income tend to choose a town where the neighborhood is richer. Note that relative income is significantly negatively correlated with happiness; if other people are richer, respondents feel unhappier (Table 6). In contrast, positive and significant coefficients of relative income indicate that those who have a higher income reference income (i.e., either others' household income or one's own aspirational income is larger than own income), which significantly and negatively affect happiness, tend to choose a town of higher-income reference group. This suggests that they tend to make a choice which could make themselves feel less happy. This individual choice is involved with one particular comparison group which is neighbor. Thus, for people who chose other reference groups for income comparisons, the relative income might not act as a significant determinant for the decision of living environment. Thus, we first include binary indicators for 12 comparison groups into the model. In addition, we estimate with the restricted sample to those who chose neighborhood as their comparison group. In either case, we find the results do not change ${ }^{21}$.

${ }^{21}$ Table 8 only reports the first case when binary indicators of comparison groups are controlled for. When the restricted sample is used, the direction and statistical significance of coefficients obtained are identical to the results of Table 8. The size of coefficients is larger in the model with the restricted sample, which means the effect of relative income is stronger among those who chose neighborhood as 
The paradoxical relationship between relative income and happiness and individual choice is, however, not observed among those who have high relative consciousness in Japan (Table 8). Those who are highly conscious of others tend to choose a town where a lower-income reference group lives. We predict that the effect of relative income on an individual's choice of town can be heterogeneous, depending on the degree of relative consciousness, as we observe the statistically significant integrated effect on happiness. Table 9 provides a statistical test of this hypothesis. The interaction terms between high relative consciousness and high relative income are negative and statistically significant ${ }^{22}$. This indicates that while people with higher-income reference groups on average make a choice that could lead to unhappiness, if they have higher relative consciousness, they make a different choice. They choose a town with a lower-income reference group. The low-income neighborhood will make their own relative status higher, which in turn would make them feel happier. Note that estimations of Table 9 are also conducted with binary indicators for 12 comparison groups (Columns (1) and (3)). We also restricted our sample to those who chose neighborhood as their comparison group (Columns (2) and (4)). The coefficients of interaction term are negative and statistically significant; the effects are even stronger with the restricted sample.

\subsection{Robustness Check}

In this section, we discuss whether the coefficients of the main estimations are robust and stable, following the method of Oster (2016). A long-standing controversy over the happiness regressions is the endogeneity of self-declared income of reference group. We examine the effect of relative status in terms of income on happiness. However, it can be, rather reversely, explained in a way that respondents think others earn more because they are unhappy. Using the results of Eq. (2), we checked, albeit partly, the effects of omitted variable bias. The approach of Oster (2016) provides significant information about the potential effect of omitted variable bias on estimated coefficients. Table 10 reports the results. The dependent variable is the degree of happiness and we report three main confounding variables: household income in actual terms, relative income, and relative consciousness. The uncontrolled regression in both panels includes only age and gender. The controlled regressions recall the specifications of Table 3 and Table 5.

In Table 10, Column (1) shows treatment effects, standard errors, and $R$-squared values when only age and gender are controlled for. The following Column (2) reports results for the full control set. The results of relative consciousness indicate that the more respondents are conscious of others' living standards, the less they report being happy in Japan. The size of the relative

comparison group.

${ }^{22}$ When the interaction terms are constructed with binary indicators of social comparison income and aspiration comparison income, the direction of coefficients are same but they are not statistically significant. 
consciousness effect is reduced with a full set of control variables, but the effect remains significant. The results for the U.S. in Panel B can be interpreted in the opposite way. Relative consciousness is positively correlated with happiness in the U.S. with and without the control variables, but the effect is smaller with controls. Household income in absolute terms increases the degree of happiness in both Japan and the U.S. In contrast, the three types of relative income have negative coefficients in both countries. This indicates that having a low relative status while surrounded by a high-income reference group makes respondents feel less happy.

In order to investigate whether this statistically significant link is not affected by omitted variable bias, we report two values for a robustness check. First, we calculated the value of $\delta$ for which $\beta=0$. This indicates the degree of selection on unobservables relative to observables that would be necessary to invalidate the result. If the value of $\delta$ is 1 , it can be interpreted as meaning that the observables would be at least as important as the unobservables, if the unobservables were included in the regression. Thus, a value of $\delta$ that exceeds 1 means unobservables would have to be more important than observables in order to explain away a result. More specifically, the $\delta$ of 2.158 that is found in the effect of absolute income on happiness in Japan can be interpreted as meaning that unobservables would have to be 2.158 times as important as observables in order to drive the observed coefficient to zero, were the unobservables to be included. Our overall results suggest that it is unlikely that the effect of absolute income and relative variables on happiness is due to unobservables. Social comparison income and aspiration comparison income have negative values of $\delta$, indicating that the coefficient increases in magnitude with the addition of controls. The $\delta$ of -0.789 that is found in the effect of social comparison income on happiness in Japan indicates that the coefficient of social comparison income with the full control set is larger in magnitude than that of the base control set. Graham et al. (2016) argue that negative results are unlikely to be driven by omitted variables. This is because going from zero to the full set of controls strengthens the coefficients of interest when $\delta$ is negative. This makes it unlikely that including additional unobservables would drive the coefficient to zero.

Secondly, we report an identified set of bounds for $\beta$, using bounds on $R_{\max }$ and $\delta . R_{\max }$ is calculated as the $R$-squared in the regression with controls $(\tilde{R})$ multiplied by 1.3 . We use the $\mathrm{R}$-squared from each specification as $\tilde{R}$, which is reported in Column (5) of Table 10. The identified set is bounded below by $\tilde{\beta}$, which we obtain when $R_{\max }=1$, and above by $\beta^{*}$, calculated based on $R_{\max }=1.3 \tilde{R}$ and $\tilde{\delta}=1$ (see Oster (2016) for details). This set gives bounds for the different estimated coefficients. All identified sets in Table 10 exclude zero. Oyster (2016) explains that one should use the rule of accepting the effect as causal only if the identified set excludes zero. In summary, for absolute income, relative income, and relative consciousness, the set $\left[\tilde{\beta}, \beta^{*}(\min \{1.3 \tilde{R}, 1\}, 1)\right]$ excludes zero, and the $\delta$ which produces $\beta=0$ with $R_{\max }=$ $1.3 \tilde{R}$ exceeds 1 . This suggests that our estimated coefficients for these three variables are unlikely 
to be affected by omitted variable bias in either country.

\section{Discussion and Conclusion}

\subsection{Relative Consciousness and Choices of Reference Group}

Our main finding is that people's consciousness of others' standard of living matters for happiness in both countries. Furthermore, the effects of relative consciousness on happiness are opposite in Japan and the U.S. We find that many people do not particularly care about others' living standards in Japan. However, those who are conscious of others' income in Japan report a lower level of happiness. In contrast, many more people in the U.S. respond that they are conscious of others' living standards; relative consciousness is positively correlated with happiness in the U.S.

We find that relative consciousness affects happiness in association with relative income status. In Japan, relative consciousness appears to affect happiness independently of relative income, as we find the interaction between relative consciousness and relative income, when other variables are held equal, fails to achieve statistical significance. This can be compared with the result of Table 4 where in Japan, increasingly huge gaps in relative income are significantly correlated with high consciousness. Although those who report a larger gap in relative income are more likely to be conscious of others, both are not necessarily interacted to decrease the relative utility. In contrast, highly conscious people who have a low-income reference group in the U.S., which makes their relative status higher, report significantly higher happiness. This makes the overall effect of relative consciousness on happiness positive in the U.S. The statistically significance of interaction terms are found in all three measures of relative income. The integrated effect suggests the possibility that highly conscious people endogenously choose low-income earners as their reference group in the U.S.

The reference group is assumed to be exogenously given and it is often assumed that it is same for all people in a given environment. In contrast, Falk and Knell (2004) present a social comparison model with endogenous reference standards. They argue that people choose similar others in a systematic and predictable way. Regarding this endogenous choice of reference group, the psychological literature provides two motives, called "self-enhancement" and "selfimprovement" (Wood and Taylor, 1991). According to the motive of "self-enhancement," individuals who are concerned about their relative status prefer low-income reference groups. They choose lower income earners as their reference group because the poorer reference group makes them feel happier. On the other hand, the self-improvement motive brings some indirect benefit from a comparison with a high-income reference group. For example, setting a higher goal (in this case, comparing themselves with a higher income reference group) could lead a person to perform better and improve their situation. Falk and Knell (2004) argue that people optimally 
choose their reference standard by balancing the two motives and investigate what happens when individuals can partly choose their reference groups. They find that the optimal reference level increases with one's own abilities, which is a testable prediction.

These self-enhancement and self-improvement tendencies are both observed among highly conscious people in the U.S., although the self-enhancement effect is stronger and statistically significant. In other words, the decrease in happiness that results from the combination of intensity of relative consciousness and self-improvement is not large enough to eliminate the average positive effect of relative consciousness on happiness in the U.S. Thus, the motive of self enhancement that comes from using a low-income reference group makes highly conscious people in the U.S. feel much happier.

\subsection{Happiness and Utility}

We have attempted to investigate how individual choices are made, in the sense that choices serve to maximize the expected stream of utility and/or happiness. We find that people, in particular less conscious people, are likely to make choices which could lower their feeling of happiness. We analyze this result in three aspects based on prior research.

First, we focus on some arguments made previously on the possible mechanisms behind the misprediction of utility (see Frey and Stutzer (2014) for details). For instance, if we divide possible costs and benefits considered in the decision-making procedure (e.g., job offer, assessment of housing, etc.) into economic and non-economic attributes, people find it much easier to justify their decisions when absolute economic payoffs are salient (e.g., higher wage, or the cost per unit area of living space). However, non-economic, intrinsic components (e.g., leisure time, feelings about new neighbors) tend to carry little weight (Hsee et al., 2003; Prelec and Herrnstein 1991); people put more weight on absolute economic payoffs and underestimate the non-economic concerns.

Frey and Stutzer (2014) provide their own empirical finding that people incorrectly predict future utility due to underestimation of non-economic attributes. They use an analysis of commuting time in association with happiness. People find their commuting time unpleasant but need to endure it for monetary or nonpecuniary benefits associated with a better job or residential location (Rosen, 1986). In this case, in a regression of happiness on commuting time, a zero coefficient is expected. However, using the SOEP data, Frey and Stutzer (2014) find a significant negative correlation between commuting time and happiness, even when they control for wealth using individual fixed effects. They explain that one interpretation is that people mispredict their future utility by underestimating intrinsic attributes, such as time with family or friends. People might expect that extra money from lower rent and a higher wage could offset the loss associated with intrinsic aspects; however, commuting results in people having less time with their families, 
which in turn reduces the overall level of happiness. In other words, they incorrectly predict the future relative utility of the things they obtain with the extra income.

Second, another possible interpretation is that happiness is not "utility", which it is often assumed to be, since happiness is not maximized by individual choice. Happiness has been considered to be a reasonable measure of the economic notion of decision utility, which assumes individuals make decisions that maximize their utility. However, some studies have argued that we need to be cautious in asserting a direct link between happiness and utility. Kimball and Willis (2006) argue that individuals' choices that are not expected to maximize their happiness can be interpreted as evidence that happiness and utility are not the same thing: there is more to life than happiness. People's choice of a town with a high-income reference group is related to preferences that include goals beyond a selfish purpose to maximize their own pleasure. To accomplish those goals, they would be willing to sacrifice their own happiness to benefit others. For example, they want to purchase nice things for their family with the extra money and provide a better life for their children, despite the extra distance and additional commuting time. Our results for the U.S. indicate that people who have a child under age 6 tend to choose a high-income reference town. They may choose a desirable residential location that enables their children to attend a better school and to buy nice things for children using the extra money. In this case, people are willing to trade off happiness against other monetary or nonpecuniary benefits that increase utility. In this regard, lower happiness does not contradict utility maximizing behavior. In other words, this can be a rational choice although it makes them endure unpleasant feelings that come from their lower relative status.

Based on the arguments raised in Frey and Stutzer (2014) and Kimball and Willis (2006), the intuition behind our results about decisions is as follows. People might mispredict their utility because they underestimate non-economic intrinsic attributes, such as lowered feeling of happiness due to higher-income neighborhood. Our survey question explicitly states that there will be no difference in the degree of safety and convenience; however, there might be other absolute economic benefits for living richer town, such as exclusive housing or a better school for their kids. If they provide rationalistic justifications for extrinsic rather than intrinsic components, this can partly account for the paradoxical observations in our results. Alternatively, we can see that there are intrinsic, nonpecuniary benefits that are components of utility, which is not directly related to one's own happiness. In other words, these non-economic rewards increase utility, although they involve a sacrifice in terms of the feeling of happiness. The difference between these two interpretations is whether we regard a decision lowering happiness as misprediction of utility or as a rational choice to increase the utility which is not same as happiness.

Finally, Clark et al. (2008) explain that happiness is an evaluation of what has occurred, and such an evaluation may not be the same as what people "expected" to happen. They note that 
"utility guides individual choice in the sense that choices serve to maximize the expected stream of utility." As behavior is driven by expectations and not necessarily by realized outcome, observed happiness may then not be the same construct as expected happiness. It should also be noted that happiness can be wrongly measured due to survey questions that affect the choices of respondents regarding happiness (Bertrand and Mullainathan, 2001). For example, the choice of town might capture an unobserved effect. Although respondents are unhappy if the income of a reference group is higher than their own, they still want to live in a town where neighbors have a high socioeconomic status. This may be because, although our survey explicitly states that safety and other conditions are same, respondents may still presume that better living conditions will flow from the higher incomes in the neighborhood.

The main contribution of this paper is to demonstrate the importance of relative consciousness on the degree of happiness and individual decision. It can affect happiness differently by country and further by the income level of comparison group. The comparison intensity increases happiness in the U.S., while the opposite result is observed in Japan. For this contradiction, we find that how the effect of relative consciousness on happiness depends on to whom people intensively compare themselves. Highly conscious people in the U.S. tend to choose low-income reference group, which is the reason for the positive coefficient of relative consciousness on happiness. The effect of relative consciousness is also found with respect to an individual's decision. Being conscious would help to make a decision that maximizes the feeling of happiness. Those who feel less happy due to higher-income reference group consciously choose a place to live with lower-income neighbors. The mechanism for how and why this determinant helps people to maximize happiness through individual choices (and, indeed, whether it does) is a topic for future study with a better measure of utility-maximizing behavior. 


\section{References}

Bartolini, S., Bilancini, E., and Sarracino, F. (2013). Predicting the trend of well-being in Germany: How much do comparisons, adaptation and sociability matter? Social Indicators Research, 114, 169-191.

Bertrand, M., and Mullainathan, S. (2001). Do people mean what they say? Implications for subjective survey data. American Economic Review, 91(2), 67-72.

Blanchflower, D. G., and Oswald, A. J. (2004). Well-being over time in Britain and the USA. Journal of Public Economics, 88(7-8), 1359-86.

Brown, Gordon D. A., Gardner, J., Oswald, A., and Qian, J. (2008). Does wage rank affect employees' well-being? Industrial Relations, 47, 355-389.

Carroll, N., Frijters, P., and Shields, M. A. (2009). Quantifying the costs of drought: new evidence from life satisfaction data. Journal of Population Economics, 22(2), 445-461.

Clark, A. E. (1999). Are wages habit-forming? Evidence from micro data. Journal of Economic Behavior \& Organization, 39, 179-200.

Clark, A. E., Frijters, F., and Shields, M. A. (2008). Relative income, happiness, and utility: An explanation for the Easterlin Paradox and other puzzles. Journal of Economic Literature, 46(1), 95-144.

Clark, A. E., and Oswald, A. J. (1996). Satisfaction and comparison income. Journal of Public Economics, 61(3), 359-81.

Clark, A. E., and Senik, C. (2010). Who compares to whom? The anatomy of income comparisons in Europe. The Economic Journal, 120(544), 573-594.

Clark, A. E., Senik, C., and Yamada, K. (2013). The Joneses in Japan: Income comparisons and financial satisfaction. ISER Discussion Paper, No. 866.

Clark, A. E., Senik, C., and Yamada, K. (2017). When experienced and decision utility concur: The case of income comparisons. Journal of Behavioral and Experimental Economics, 70, $1-9$.

de la Garza, A., Mastrobuoni, G., Sannabe, A., and Yamada, K. (2012). The relative utility hypothesis with and without self-reported reference wages. ISER Discussion Paper, No. 164.

Oshio, T., and Urakawa, K. (2014). The association between perceived income inequality and subjective well-being: Evidence from a social survey in Japan. Social Indicators Research, 116 (3), 755-770.

Di Tella, R., New, Haisken-De J., and MacCulloch, R. (2007). Happiness adaptation to income and to status in an individual panel. NBER Working Paper, No. 13159.

Dolan, P., Peasgood, T., and White, M. (2008). Do we really know what makes us happy? A 
review of the economic literature on the factors associated with subjective well-being. Journal of Economic Psychology, 29(1), 94-122.

Easterlin, R. A. (1974). Does Economic Growth Improve the Human Lot? Some Empirical Evidence. In Paul A. D. and Melvin W. R. (Eds.), Nations and Households in Economic Growth: Essays in Honor of Moses Abramowitz. New York: Academic Press. pp 89-125.

Easterlin, R. A. (2001). Income and happiness: Towards a unified theory. The Economic Journal, 111(473), 465-84.

Easterlin, R. A. (2006). Life cycle happiness and its sources: Intersections of psychology, economics, and demography. Journal of Economic Psychology, 27(4), 463-482.

Godechot, O., and Senik, C. (2015). Wage comparisons in and out of the firm. Evidence from a matched employer-employee French database. Journal of Economic Behavior \& Organization, 117, 395-410.

Goerke, L., and Pannenberg, M. (2015). Direct evidence for income comparisons and subjective well-being across reference groups. Economics Letter, 137, 95-101.

Graham, B. A. T., Miller, M. K., and Strom, K. W. (2017). Safeguarding democracy: powersharing and democratic survival. American Political Science Review, 111(4), 686704.

Hauret, L., and Williams, D. R. (2017). Relative income and pay satisfaction: Further evidence on the role of the reference group. Journal of Happiness Studies, https://doi.org/10.1007/s10902-017-9950-2

Hirschman, A. O., and Rothschild, M. (1973). The changing tolerance for income inequality in the course of economic development. The Quarterly Journal of Economics, 87(4), 544566.

Hollander, H. (2001). On the validity of utility statements: standard theory versus Duesenberry's. Journal of Economic Behavior \& Organization, 45, 227-249.

Hsee, C. K., Zhang, J., Yu, F., and Xi, Y. (2003). Lay rationalism in decision making. Journal of Behavioral Decision Making, 16, 257-272.

Kahneman, D., Diener, E., and Schwarz, N. (1999). Well-Being: The Foundations of Hedonic Psychology. New York: Russell Sage Foundation.

Kahneman, D., and Krueger, A. B. (2006). Developments in the measurement of subjective well-being. Journal of Economic Perspectives, 20, 3-24.

Kimball, M. and Willis, R. (2006). Utility and Happiness. University of Michigan. Ann Arbor, $1-67$.

Knight, J., Song, L. and Gunatilaka, R. (2009). Subjective well-being and its determinants in rural China. China Economic Review, 20, 635-649.

Ferrer-i-Carbonell, A. (2005). Income and well-being: An empirical analysis of the comparison 
income effect. Journal of Public Economics, 89(5-6), 997-1019.

Frey, B. S., Benz, M., and Stutzer, A. (2004). Introducing procedural utility: Not only what, but also how matters. Journal of Institutional and Theoretical Economics, 160(3), 377- 401.

Frey, B. S., and Stutzer, A. (2014). Economic consequences of mispredicting utility. Journal of Happiness Studies, 15, 937-956.

Falk, A., and Knell, M. (2004). Choosing the Joneses: Endogenous goals and reference standards. Scandinavian Journal of Economics, 106(3), 417-35.

Layard, R. (2005). Happiness: Lessons from a New Science. London: Allen Lane.

Luttmer, Erzo F. P. (2005). Neighbors as negatives: relative earnings and well-being. Quarterly Journal of Economics, 120(3), 963-1002.

Mayraz, G., Wagner, G. G., and Schupp, J. (2009). Life satisfaction and relative income: Perceptions and evidence, SOEPpapers, No. 214.

McBride, M. (2006). Money, happiness, and aspiration formation: An experimental study. Journal of Economic Behavior \& Organization, 74, 262-276.

McBride, M. (2010). Money, happiness and aspirations: an experimental study. Journal of Economic Behavior \& Organization, 74, 262-276.

Oster, E. (2016). Unobservable selection and coefficient stability: Theory and validation. Journal of Business Economics and Statistics, doi: 10.1080/07350015.2016.1227711.

Prelec, D., and Herrnstein, R. J. (1991). Preferences or Principles: Alternative Guidelines for Choice. In Richard J. Zeckhauser (Eds.), Strategy and Choice. Cambridge: MIT Press.

Rosen, S. (1986). The Theory of Equalizing Differences. In Ashenfelter, O., and Card, D. (Eds.), Handbook of Labor Economics (vol. 1). Elsevier: Amsterdam. pp. 641-692.

Senik, C. (2009). Direct evidence on income comparisons and their welfare effects, Journal of Economic Behavior \& Organization, 72, 408-424.

Stutzer, A. (2004). The role of income aspirations in individual happiness. Journal of Economic Behavior and Organization, 54(1), 89-109.

Vendrik, M. (2013). Adaptation, anticipation and social interaction in happiness: An integrated error-correction approach. Journal of Public Economics, 105, 131-149.

Wood, J. V., and Taylor, K. L. (1991). Serving Self-Relevant Goals through Social Comparison. In J. Suls and T. A. Wills (Eds.), Social Comparison: Contemporary Theory and Research. Hillsdale, NJ: Erlbaum Associates, Inc. pp. 23-49.

Yamada, K. and Sato, M. (2013). Another avenue for anatomy of income comparisons: Evidence from hypothetical choice experiments. Journal of Economic Behavior \& Organization, 89(C), 35-57. 


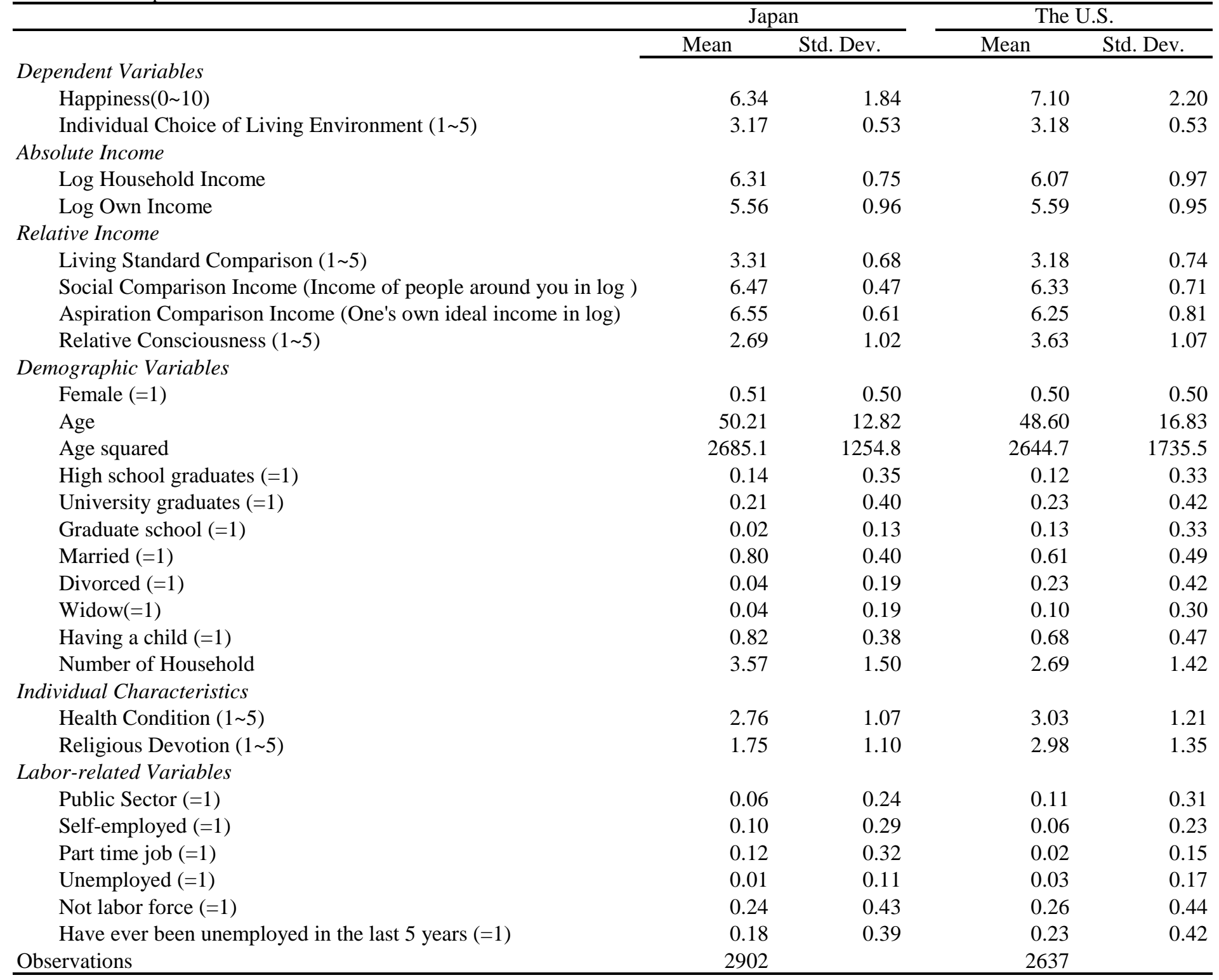

NOTES: All variables are summarized with the sample used to analyze determinants of happiness (Table 3). Relative Consciousness and Individual choice of living environment are described with samples used to Column (1) of Table 5 and Table 8. 
Table 2. Happiness by Income Group

\begin{tabular}{|c|c|c|c|c|c|c|c|c|}
\hline \multirow[b]{2}{*}{$\begin{array}{l}\text { Degree of } \\
\text { Happiness }\end{array}$} & \multicolumn{4}{|c|}{ Japan (unit: \%) } & \multicolumn{4}{|c|}{ The U.S. (unit: \%) } \\
\hline & $\begin{array}{l}\text { Whole } \\
(\mathrm{n}=3063)\end{array}$ & $\begin{array}{l}\text { Low } \\
\text { Income } \\
(n=904)\end{array}$ & $\begin{array}{l}\text { Middle } \\
\text { Income } \\
(n=1195)\end{array}$ & $\begin{array}{l}\text { High } \\
\text { Income } \\
(n=964)\end{array}$ & $\begin{array}{l}\text { Whole } \\
(\mathrm{n}=2846)\end{array}$ & $\begin{array}{l}\text { Low } \\
\text { Income } \\
(n=1151)\end{array}$ & $\begin{array}{l}\text { Middle } \\
\text { Income } \\
(n=904)\end{array}$ & $\begin{array}{l}\text { High } \\
\text { Income } \\
(n=791)\end{array}$ \\
\hline 0 (Lowest) & 0.2 & 0.6 & 0.0 & 0.0 & 0.9 & 1.5 & 0.9 & 0.3 \\
\hline 1 & 0.8 & 1.4 & 0.3 & 0.6 & 1.1 & 1.6 & 1.3 & 0.5 \\
\hline 2 & 1.3 & 2.1 & 0.9 & 0.9 & 2.4 & 3.6 & 1.3 & 2.1 \\
\hline 3 & 4.6 & 7.1 & 4.9 & 3.2 & 3.8 & 5.1 & 2.9 & 3.5 \\
\hline 4 & 5.2 & 7.9 & 6.3 & 3.3 & 4.0 & 4.2 & 4.9 & 2.8 \\
\hline 5 & 22.5 & 30.4 & 22.3 & 16.2 & 10.4 & 14.4 & 10.2 & 6.2 \\
\hline 6 & 14.7 & 14.5 & 16.2 & 13.2 & 8.7 & 10.4 & 10.2 & 6.7 \\
\hline 7 & 22.4 & 16.9 & 22.8 & 25.3 & 13.4 & 14.0 & 12.4 & 15.5 \\
\hline 8 & 18.2 & 12.4 & 17.3 & 22.9 & 26.2 & 21.2 & 27.7 & 29.8 \\
\hline 9 & 5.7 & 4.1 & 4.6 & 8.0 & 16.9 & 12.3 & 17.5 & 21.1 \\
\hline 10 (Highest) & 4.5 & 2.7 & 4.2 & 6.3 & 12.3 & 11.6 & 10.8 & 11.4 \\
\hline
\end{tabular}

NOTES: After categorizing the household income data into three groups using the $25 \%$ and $75 \%$ percentile

thresholds as separators, the percentage of each scale of happiness by income group is reported. 


\begin{tabular}{|c|c|c|c|c|c|c|c|c|}
\hline \multirow[t]{2}{*}{ Y: Degree of Happiness $(0 \sim 10)$} & \multicolumn{4}{|l|}{ Japan } & \multicolumn{4}{|l|}{ The U.S. } \\
\hline & $(1)$ & (2) & (3) & (4) & (1) & (2) & (3) & (4) \\
\hline \multicolumn{9}{|l|}{ Absolute Income } \\
\hline Log Household Income & $\begin{array}{l}0.4243 * * * \\
(0.050)\end{array}$ & $\begin{array}{l}0.2998 * * * \\
(0.050)\end{array}$ & $\begin{array}{l}0.4892 * * * \\
(0.060)\end{array}$ & $\begin{array}{l}0.5878 * * * \\
(0.077)\end{array}$ & $\begin{array}{l}0.2680 * * * \\
(0.052)\end{array}$ & $\begin{array}{l}0.2246 * * * \\
(0.053)\end{array}$ & $\begin{array}{l}0.3663 * * * \\
(0.064)\end{array}$ & $\begin{array}{l}0.3433 * * * \\
(0.088)\end{array}$ \\
\hline \multicolumn{9}{|l|}{ Relative Income } \\
\hline $\begin{array}{l}\text { Living Standard Comparison } \\
\text { (5: Theirs is much higher than mine) }\end{array}$ & & $\begin{array}{l}-0.5214 * * * \\
(0.048)\end{array}$ & & & & $\begin{array}{l}-0.2592 * * * \\
(0.058)\end{array}$ & & \\
\hline $\begin{array}{l}\text { Social Comparison Income } \\
\text { (Income of People Around You) }\end{array}$ & & & $\begin{array}{l}-0.1737 * * \\
(0.080)\end{array}$ & & & & $\begin{array}{l}-0.2008 * * * \\
(0.077)\end{array}$ & \\
\hline $\begin{array}{l}\text { Aspiration Comparison Income } \\
\text { (One's Own Ideal Income) }\end{array}$ & & & & $\begin{array}{l}-0.2390^{* * *} \\
(0.087)\end{array}$ & & & & $\begin{array}{l}-0.1027 \\
(0.097)\end{array}$ \\
\hline Observations & 2,894 & 2,883 & 2,692 & 2,778 & 2,502 & 2,497 & 2,452 & 2,466 \\
\hline R-Squared & 0.159 & 0.191 & 0.164 & 0.163 & 0.123 & 0.129 & 0.127 & 0.125 \\
\hline
\end{tabular}

NOTES: Variables listed under "Demographic Variables", "Individual Characteristics", and "Labor-related Variables" in Table 1 (which are reported in Table 6) are all controlled for. Standard errors in parentheses *** $\mathrm{p}<0.01, * * \mathrm{p}<0.05,{ }^{*} \mathrm{p}<0.1$ 
Table 4. Relative Consciousness and Main Variables

\begin{tabular}{|c|c|c|c|c|c|c|}
\hline \multicolumn{7}{|l|}{ Panel A } \\
\hline \multirow[b]{2}{*}{ Relative Consciousnes } & \multicolumn{6}{|c|}{ Japan } \\
\hline & Percentatge & $\begin{array}{l}\text { Absolute } \\
\text { Income }\end{array}$ & $\begin{array}{r}\text { Living } \\
\text { Standard } \\
\text { Comparison }\end{array}$ & $\begin{array}{r}\text { Social } \\
\text { Comparison } \\
\text { Income }\end{array}$ & \multicolumn{2}{|c|}{$\begin{array}{r}\text { Aspiration } \\
\text { Comparison } \\
\text { Income }\end{array}$} \\
\hline & (1) & (2) & (3) & (4) & & (5) \\
\hline Low and Lower & 0.430 & 6.268 & 3.249 & -0.005 & & 0.087 \\
\hline Neither Low Nor High & 0.338 & 6.318 & 3.319 & 0.025 & & 0.107 \\
\hline High and Higher & 0.232 & 6.361 & 3.386 & 0.043 & & 0.130 \\
\hline \multirow[b]{2}{*}{ Relative Consciousnes } & \multicolumn{6}{|c|}{ The U.S. } \\
\hline & Percentatge & $\begin{array}{l}\text { Absolute } \\
\text { Income }\end{array}$ & $\begin{array}{c}\text { Living } \\
\text { Standard } \\
\text { Comparison }\end{array}$ & $\begin{array}{r}\text { Social } \\
\text { Comparison } \\
\text { Income }\end{array}$ & $\begin{array}{r}\mathrm{As} \\
\mathrm{Com}\end{array}$ & $\begin{array}{l}\text { piration } \\
\text { parison } \\
\text { Income }\end{array}$ \\
\hline & (1) & (2) & (3) & (4) & & (5) \\
\hline Low and Lower & 0.147 & 5.856 & 3.267 & 0.057 & & 0.022 \\
\hline Neither Low Nor High & 0.254 & 6.117 & 3.120 & 0.027 & & 0.021 \\
\hline High and Higher & 0.599 & 6.099 & 3.183 & 0.048 & & 0.029 \\
\hline \multicolumn{7}{|l|}{ Panel B } \\
\hline \multirow[t]{2}{*}{ Y: Relative Consciousness (1 5) } & \multicolumn{3}{|c|}{ Japan } & \multicolumn{3}{|c|}{ The U.S. } \\
\hline & (1) & (2) & (3) & (1) & (2) & (3) \\
\hline $\begin{array}{r}\text { Absolute Income } \\
\text { Log Household Income }\end{array}$ & $\begin{array}{l}0.0774 * * * \\
(0.030)\end{array}$ & $\begin{array}{l}0.1048^{* * *} \\
(0.034)\end{array}$ & $\begin{array}{l}0.0513 * \\
(0.030)\end{array}$ & $\begin{array}{l}0.0223 \\
(0.027)\end{array}$ & $\begin{array}{l}0.0272 \\
(0.029)\end{array}$ & $\begin{array}{l}0.030 \\
(0.03)\end{array}$ \\
\hline Relative Income & & & & & & \\
\hline $\begin{array}{l}\text { Living Standard Comparison } \\
\text { (5: Theirs is much higher than mine) }\end{array}$ & $\begin{array}{l}0.1129 * * * \\
(0.029)\end{array}$ & & & $\begin{array}{l}-0.0207 \\
(0.030)\end{array}$ & & \\
\hline $\begin{array}{l}\text { Social Comparison Income } \\
\text { (Income of People Around You) }\end{array}$ & & $\begin{array}{l}0.1870 * * * \\
(0.050)\end{array}$ & & & $\begin{array}{l}0.0156 \\
(0.055)\end{array}$ & \\
\hline $\begin{array}{l}\text { Aspiration Comparison Income } \\
\text { (One's Own Ideal Income) }\end{array}$ & & & $\begin{array}{l}0.1708^{* *} \\
(0.085)\end{array}$ & & & $\begin{array}{l}-0.016 \\
(0.07)\end{array}$ \\
\hline
\end{tabular}

NOTES: Panel A summarizes the mean values of happiness sorted by income at both absolute and relative terms. Panel $B$ reports the estimation results of a regression of relative consciousness on income variables; individual demographic and labor-related variables (which are used in Table 6) are all controlled for. 
Table 5. Happiness and Relative Consciousness

\begin{tabular}{|c|c|c|c|c|c|c|c|c|c|c|}
\hline \multirow[t]{2}{*}{ Y: Degree of Happiness $(0 \sim 10)$} & \multicolumn{5}{|l|}{ Japan } & \multicolumn{5}{|l|}{ The U.S. } \\
\hline & $(1)$ & $(2)$ & (3) & $(4)$ & $(5)$ & $(1)$ & $(2)$ & (3) & (4) & $(5)$ \\
\hline $\begin{array}{l}\text { How much are you conscious of others' living standards? } \\
\text { Relative Consciousness }(1 \sim 5) \\
\text { (Base: } 5 \text { ) }\end{array}$ & $\begin{array}{l}-0.2571^{* * * *} \\
(0.032)\end{array}$ & & $\begin{array}{l}-0.2349 * * * \\
(0.031)\end{array}$ & $\begin{array}{l}-0.2509 * * * \\
(0.033)\end{array}$ & $\begin{array}{l}-0.2571 * * * \\
(0.032)\end{array}$ & $\begin{array}{l}0.0977 * * \\
(0.039)\end{array}$ & & $\begin{array}{l}0.0956^{* * *} \\
(0.039)\end{array}$ & $\begin{array}{l}0.0895^{* *} \\
(0.040)\end{array}$ & $\begin{array}{l}0.0928 * * \\
(0.039)\end{array}$ \\
\hline Relative Consciousness 1 & & $\begin{array}{l}0.9217 * * * \\
(0.241)\end{array}$ & & & & & $\begin{array}{l}-0.2633 \\
(0.220)\end{array}$ & & & \\
\hline Relative Consciousness 2 & & $\begin{array}{l}0.6624 * * * \\
(0.233)\end{array}$ & & & & & $\begin{array}{l}-0.5109 * * * \\
(0.159)\end{array}$ & & & \\
\hline Relative Consciousness 3 & & $\begin{array}{l}0.2864 \\
(0.232)\end{array}$ & & & & & $\begin{array}{l}-0.2504 * * \\
(0.121)\end{array}$ & & & \\
\hline Relative Consciousness 4 & & $\begin{array}{l}0.1792 \\
(0.234)\end{array}$ & & & & & $\begin{array}{l}-0.3198 * * * \\
(0.111)\end{array}$ & & & \\
\hline Relative Income & & & & & & & & & & \\
\hline $\begin{array}{l}\text { Living Standard Comparison } \\
\text { (5: Theirs is much higher than mine) }\end{array}$ & & & $\begin{array}{l}-0.4907 * * * \\
(0.048)\end{array}$ & & & & & $\begin{array}{l}-0.2618 * * * \\
(0.058)\end{array}$ & & \\
\hline $\begin{array}{l}\text { Social Comparison Income } \\
\text { (Income of People Around You) }\end{array}$ & & & & $\begin{array}{l}-0.1267 \\
(0.079)\end{array}$ & & & & & $\begin{array}{l}-0.2100 * * * \\
(0.077)\end{array}$ & \\
\hline $\begin{array}{l}\text { Aspiration Comparison Income } \\
\text { (One's Own Ideal Income) }\end{array}$ & & & & & $\begin{array}{l}-0.2050 * * \\
(0.086)\end{array}$ & & & & & $\begin{array}{l}-0.1297 \\
(0.097)\end{array}$ \\
\hline $\begin{array}{l}\text { Absolute Income } \\
\text { Log Household Income }\end{array}$ & $\begin{array}{l}0.4382 * * * \\
(0.049)\end{array}$ & $\begin{array}{l}0.4376^{* * * *} \\
(0.049)\end{array}$ & $\begin{array}{l}0.3207 * * * \\
(0.050)\end{array}$ & $\begin{array}{l}0.4858 * * * \\
(0.059)\end{array}$ & $\begin{array}{l}0.5777 * * * \\
(0.076)\end{array}$ & $\begin{array}{l}0.2715 * * * \\
(0.052)\end{array}$ & $\begin{array}{l}0.2814 * * * \\
(0.052)\end{array}$ & $\begin{array}{l}0.2275^{* * *} \\
(0.053)\end{array}$ & $\begin{array}{l}0.3744 * * * \\
(0.064)\end{array}$ & $\begin{array}{l}0.3666^{* * * *} \\
(0.088)\end{array}$ \\
\hline $\begin{array}{l}\text { Observations } \\
\text { R_Squared }\end{array}$ & 2,891 & 2,891 & 2,880 & 2,691 & 2,775 & 2,489 & 2,489 & 2,484 & 2,440 & 2,454 \\
\hline R-Squared & 0.178 & 0.179 & 0.206 & 0.182 & 0.182 & 0.126 & 0.128 & 0.133 & 0.130 & 0.129 \\
\hline
\end{tabular}

NOTES: Individual demographic and labor-related variables (which are used in Table 6) are all controlled for.

Standard errors in parentheses $* * * \mathrm{p}<0.01, * * \mathrm{p}<0.05, * \mathrm{p}<0.1$ 
Table 6. Determinants of the Degree of Happiness using Panel Data

\begin{tabular}{|c|c|c|c|c|c|c|c|c|}
\hline \multirow{3}{*}{ Y: Degree of Happiness $(0 \sim 10)$} & \multicolumn{4}{|l|}{ Japan } & \multicolumn{4}{|l|}{ The U.S. } \\
\hline & (1) Cross & (2) Fixed & (3) Random & (4) Fixed & (1) Cross & (2) Fixed & (3) Random & (4) Fixed \\
\hline & section & Effect & Effect & (Balanced) & section & Effect & Effect & (Balanced) \\
\hline \multicolumn{9}{|l|}{ Main Control Variables } \\
\hline Log Household Income & $\begin{array}{l}0.4382^{* * * *} \\
(0.049)\end{array}$ & $\begin{array}{l}0.1893 * * * \\
(0.052)\end{array}$ & $\begin{array}{l}0.3971 * * * \\
(0.037)\end{array}$ & $\begin{array}{l}0.0812 \\
(0.062)\end{array}$ & $\begin{array}{l}0.2715^{* * * *} \\
(0.052)\end{array}$ & $\begin{array}{l}0.0312 \\
(0.149)\end{array}$ & $\begin{array}{l}0.2728^{* * * *} \\
(0.040)\end{array}$ & $\begin{array}{l}0.0379 \\
(0.149)\end{array}$ \\
\hline Relative Consciousness & $\begin{array}{l}-0.2571 * * * \\
(0.032)\end{array}$ & $\begin{array}{l}-0.1108^{* * * *} \\
(0.027)\end{array}$ & $\begin{array}{l}-0.1823 * * * \\
(0.022)\end{array}$ & $\begin{array}{l}-0.0937 * * * \\
(0.030)\end{array}$ & $\begin{array}{l}0.0977 * * \\
(0.039)\end{array}$ & $\begin{array}{l}0.1494 * \\
(0.079)\end{array}$ & $\begin{array}{l}0.1012 * * * \\
(0.030)\end{array}$ & $\begin{array}{l}0.1460 * \\
(0.079)\end{array}$ \\
\hline \multicolumn{9}{|l|}{ Demographic Variables } \\
\hline Female $(=1)$ & $\begin{array}{l}0.2018 \text { *** } \\
(0.076)\end{array}$ & & $\begin{array}{l}0.1881 * * * \\
(0.070)\end{array}$ & & $\begin{array}{l}0.0982 \\
(0.085)\end{array}$ & & $\begin{array}{l}0.1643 * * \\
(0.079)\end{array}$ & \\
\hline Age & $\begin{array}{l}-0.0394 * \\
(0.022)\end{array}$ & $\begin{array}{l}0.4990 \\
(0.529)\end{array}$ & $\begin{array}{l}-0.0299 \\
(0.020)\end{array}$ & $\begin{array}{l}0.5330 \\
(0.521)\end{array}$ & $\begin{array}{l}-0.0590 * * * \\
(0.015)\end{array}$ & $\begin{array}{l}1.3475 \\
(1.592)\end{array}$ & $\begin{array}{l}-0.0345^{* * * *} \\
(0.012)\end{array}$ & $\begin{array}{l}1.3442 \\
(1.592)\end{array}$ \\
\hline Age squared & $\begin{array}{l}0.0002 \\
(0.000)\end{array}$ & $\begin{array}{l}0.0001 \\
(0.001)\end{array}$ & $\begin{array}{l}0.0002 \\
(0.000)\end{array}$ & $\begin{array}{l}-0.0004 \\
(0.001)\end{array}$ & $\begin{array}{l}0.0006^{* * * *} \\
(0.000)\end{array}$ & $\begin{array}{l}-0.0161 \\
(0.017)\end{array}$ & $\begin{array}{l}0.0004 * * * \\
(0.000)\end{array}$ & $\begin{array}{l}-0.0160 \\
(0.017)\end{array}$ \\
\hline High school graduates & $\begin{array}{l}0.3887 * * * \\
(0.097)\end{array}$ & & $\begin{array}{l}0.6260 * * * \\
(0.124)\end{array}$ & & $\begin{array}{l}-0.0396 \\
(0.132)\end{array}$ & & $\begin{array}{l}0.3685^{*} \\
(0.198)\end{array}$ & \\
\hline University graduates & $\begin{array}{l}0.3278^{* * * *} \\
(0.086)\end{array}$ & & $\begin{array}{l}0.5923 * * * \\
(0.118)\end{array}$ & & $\begin{array}{l}0.1158 \\
(0.108)\end{array}$ & & $\begin{array}{l}0.4767 * * \\
(0.188)\end{array}$ & \\
\hline Graduate school & $\begin{array}{l}0.7699 \text { *** } \\
(0.242)\end{array}$ & & $\begin{array}{l}0.8570 \text { *** } \\
(0.248)\end{array}$ & & $\begin{array}{l}0.1694 \\
(0.137)\end{array}$ & & $\begin{array}{l}0.5752 * * * \\
(0.203)\end{array}$ & \\
\hline Married (=1) & $\begin{array}{l}0.6687^{* * * *} \\
(0.166)\end{array}$ & $\begin{array}{l}0.0455 \\
(0.054)\end{array}$ & $\begin{array}{l}0.0984^{*} \\
(0.051)\end{array}$ & $\begin{array}{l}0.0070 \\
(0.060)\end{array}$ & $\begin{array}{l}0.5221 * * * \\
(0.196)\end{array}$ & $\begin{array}{l}-0.0734 \\
(0.158)\end{array}$ & $\begin{array}{l}0.0859 \\
(0.094)\end{array}$ & $\begin{array}{l}-0.0689 \\
(0.159)\end{array}$ \\
\hline $\begin{array}{l}\text { Divorced }(=1) \\
\text { (Divorced and widow }(=1 ; \text { Japan })\end{array}$ & $\begin{array}{l}0.0529 \\
(0.221)\end{array}$ & $\begin{array}{l}-0.0833 \\
(0.135)\end{array}$ & $\begin{array}{l}-0.1956 \\
(0.126)\end{array}$ & $\begin{array}{l}-0.1747 \\
(0.160)\end{array}$ & $\begin{array}{l}0.0630 \\
(0.221)\end{array}$ & $\begin{array}{l}-0.0111 \\
(0.257)\end{array}$ & $\begin{array}{l}-0.1232 \\
(0.138)\end{array}$ & $\begin{array}{l}-0.0078 \\
(0.258)\end{array}$ \\
\hline Widow $(=1)$ & $\begin{array}{l}0.3464 \\
(0.237)\end{array}$ & & & & $\begin{array}{l}-0.1878 \\
(0.224)\end{array}$ & $\begin{array}{l}-0.0419 \\
(0.158)\end{array}$ & $\begin{array}{l}-0.4207 * * * \\
(0.088)\end{array}$ & $\begin{array}{l}-0.0517 \\
(0.158)\end{array}$ \\
\hline Having a child $(=1)$ & $\begin{array}{l}0.3765^{* * * *} \\
(0.140)\end{array}$ & $\begin{array}{l}0.3313 * \\
(0.192)\end{array}$ & $\begin{array}{l}0.5229 * * * \\
(0.091)\end{array}$ & $\begin{array}{l}0.1329 \\
(0.218)\end{array}$ & $\begin{array}{l}-0.0400 \\
(0.120)\end{array}$ & $\begin{array}{l}-0.2309 \\
(0.440)\end{array}$ & $\begin{array}{l}0.0524 \\
(0.088)\end{array}$ & $\begin{array}{l}-0.2262 \\
(0.440)\end{array}$ \\
\hline Number of Household & $\begin{array}{l}-0.0862 * * * \\
(0.025)\end{array}$ & $\begin{array}{l}-0.0083 \\
(0.035)\end{array}$ & $\begin{array}{l}-0.0650 * * * \\
(0.021)\end{array}$ & $\begin{array}{l}-0.0058 \\
(0.039)\end{array}$ & $\begin{array}{l}-0.0745^{* *} \\
(0.036)\end{array}$ & $\begin{array}{l}-0.0227 \\
(0.058)\end{array}$ & $\begin{array}{l}-0.0385^{*} \\
(0.023)\end{array}$ & $\begin{array}{l}-0.0232 \\
(0.058)\end{array}$ \\
\hline \multicolumn{9}{|l|}{ Individual Characteristics } \\
\hline Health Condition (1-5) & $\begin{array}{l}0.2787 * * * \\
(0.030)\end{array}$ & $\begin{array}{l}0.1087 * * * \\
(0.026)\end{array}$ & $\begin{array}{l}0.1978 * * * \\
(0.021)\end{array}$ & $\begin{array}{l}0.0925 * * * \\
(0.029)\end{array}$ & $\begin{array}{l}0.3204 * * * \\
(0.035)\end{array}$ & $\begin{array}{l}0.0428 \\
(0.077)\end{array}$ & $\begin{array}{l}0.3164 * * * \\
(0.027)\end{array}$ & $\begin{array}{l}0.0421 \\
(0.077)\end{array}$ \\
\hline Religious Devotion (1-5) & $\begin{array}{l}0.1607 * * * \\
(0.029)\end{array}$ & $\begin{array}{l}0.0152 \\
(0.034)\end{array}$ & $\begin{array}{l}0.0896 * * * \\
(0.023)\end{array}$ & $\begin{array}{l}-0.0143 \\
(0.040)\end{array}$ & $\begin{array}{l}0.2431 * * * \\
(0.032)\end{array}$ & $\begin{array}{l}-0.0334 \\
(0.103)\end{array}$ & $\begin{array}{l}0.2210 * * * \\
(0.026)\end{array}$ & $\begin{array}{l}-0.0231 \\
(0.104)\end{array}$ \\
\hline \multicolumn{9}{|l|}{ Labor-related Variables } \\
\hline Public Sector $(=1)$ & $\begin{array}{l}0.1504 \\
(0.112)\end{array}$ & $\begin{array}{l}-0.1953 \\
(0.204)\end{array}$ & $\begin{array}{l}0.1190 \\
(0.122)\end{array}$ & $\begin{array}{l}-0.2272 \\
(0.234)\end{array}$ & $\begin{array}{l}-0.0079 \\
(0.183)\end{array}$ & $\begin{array}{l}-0.2969 \\
(0.316)\end{array}$ & $\begin{array}{l}-0.0109 \\
(0.109)\end{array}$ & $\begin{array}{l}-0.2956 \\
(0.316)\end{array}$ \\
\hline Self-employed (=1) & $\begin{array}{l}0.1011 \\
(0.139)\end{array}$ & $\begin{array}{l}0.1881 \\
(0.118)\end{array}$ & $\begin{array}{l}0.1495^{*} \\
(0.086)\end{array}$ & $\begin{array}{l}0.1863 \\
(0.137)\end{array}$ & $\begin{array}{l}-0.0905 \\
(0.141)\end{array}$ & $\begin{array}{l}-0.1251 \\
(0.347)\end{array}$ & $\begin{array}{l}-0.0131 \\
(0.133)\end{array}$ & $\begin{array}{l}-0.1282 \\
(0.347)\end{array}$ \\
\hline Part time job $(=1)$ & $\begin{array}{l}-0.0360 \\
(0.113)\end{array}$ & $\begin{array}{l}0.0262 \\
(0.104)\end{array}$ & $\begin{array}{l}-0.0250 \\
(0.080)\end{array}$ & $\begin{array}{l}0.0590 \\
(0.117)\end{array}$ & $\begin{array}{l}0.0567 \\
(0.283)\end{array}$ & $\begin{array}{l}-0.5703 \\
(0.575)\end{array}$ & $\begin{array}{l}0.2144 \\
(0.220)\end{array}$ & $\begin{array}{l}-0.5726 \\
(0.575)\end{array}$ \\
\hline Unemployed $(=1)$ & $\begin{array}{l}0.3932 \\
(0.290)\end{array}$ & $\begin{array}{l}0.1317 \\
(0.187)\end{array}$ & $\begin{array}{l}0.0936 \\
(0.165)\end{array}$ & $\begin{array}{l}0.0624 \\
(0.204)\end{array}$ & $\begin{array}{l}-1.0532 * * * \\
(0.258)\end{array}$ & $\begin{array}{l}0.0630 \\
(0.387)\end{array}$ & $\begin{array}{l}-0.5603 * * * \\
(0.176)\end{array}$ & $\begin{array}{l}0.0650 \\
(0.387)\end{array}$ \\
\hline Not labor force $(=1)$ & $\begin{array}{l}0.2725^{* * * *} \\
(0.091)\end{array}$ & $\begin{array}{l}-0.0239 \\
(0.095)\end{array}$ & $\begin{array}{l}0.1337 * * \\
(0.068)\end{array}$ & $\begin{array}{l}-0.0259 \\
(0.110)\end{array}$ & $\begin{array}{l}0.2080^{*} \\
(0.112)\end{array}$ & $\begin{array}{l}0.0178 \\
(0.288)\end{array}$ & $\begin{array}{l}0.2544 * * * \\
(0.087)\end{array}$ & $\begin{array}{l}0.0202 \\
(0.288)\end{array}$ \\
\hline $\begin{array}{l}\text { Have ever been unemployed } \\
\text { in the last } 5 \text { years }(=1) \\
\text { _cons }\end{array}$ & $\begin{array}{l}-0.2515^{* * *} \\
(0.086) \\
3.9153^{* * *} \\
(0.579)\end{array}$ & $\begin{array}{l}-0.1004 \\
(0.075) \\
-19.9059 \\
(25.728)\end{array}$ & $\begin{array}{l}-0.2008^{* * *} \\
(0.059) \\
3.9071^{* * *} \\
(0.505)\end{array}$ & $\begin{array}{l}-0.1231 \\
(0.082) \\
-18.8573 \\
(24.971)\end{array}$ & $\begin{array}{l}-0.4151^{* * *} \\
(0.106) \\
4.7428^{* * *} \\
(0.570)\end{array}$ & $\begin{array}{l}0.3106 \\
(0.219) \\
-16.2300 \\
(37.736)\end{array}$ & $\begin{array}{l}-0.3927^{* * *} \\
(0.081) \\
3.9525^{* * *} \\
(0.417)\end{array}$ & $\begin{array}{l}0.3247 \\
(0.220) \\
-16.5066 \\
(37.833)\end{array}$ \\
\hline Observations & 2,891 & 5,481 & 5,481 & 3,858 & 2,489 & 4,253 & 4,253 & 1,324 \\
\hline $\begin{array}{l}\text { R-squared } \\
\text { Number of panelid }\end{array}$ & 0.178 & $\begin{array}{l}0.028 \\
2,226\end{array}$ & 2,226 & $\begin{array}{l}0.023 \\
1,286\end{array}$ & 0.126 & $\begin{array}{l}0.016 \\
3,588\end{array}$ & 3,588 & $\begin{array}{l}0.016 \\
662\end{array}$ \\
\hline
\end{tabular}

NOTES: Column (1) uses cross-section data of the 2006 year, which produces the same estimation results as those in Table 5 (1). The rest of Columns for Japan are based on the panel data from 2004 to 2006; while for the U.S., they are based on the panel data from 2005 and 2006. Column (4) reports the result of fixed-effect model with the balanced data. Standard errors in parentheses $* * * \mathrm{p}<0.01, * * \mathrm{p}<0.05, * \mathrm{p}<0.1$ 
Table 7. Happiness and Relative Consciousness in association with Relative Income

\begin{tabular}{|c|c|c|c|c|c|c|}
\hline \multirow{2}{*}{$\begin{array}{l}\text { Y: Degree of Happiness }(0 \sim 10) \\
\text { RI: Three measures of relative income }\end{array}$} & \multicolumn{3}{|l|}{ Japan } & \multicolumn{3}{|l|}{ The U.S. } \\
\hline & RI1 & RI2 & RI3 & RI1 & RI2 & RI3 \\
\hline & (1) & (2) & (3) & (4) & (5) & (6) \\
\hline \multicolumn{7}{|l|}{ Relative Variables } \\
\hline Low Income Reference Group (LIRG): $\delta$ & $0.6435^{* * *}$ & $0.2705 * * *$ & -0.0840 & $0.2934 *$ & -0.1260 & -0.3027 \\
\hline Equals 1 if others' living standards are low(er) or same & $(0.079)$ & $(0.094)$ & $(0.159)$ & $(0.151)$ & $(0.162)$ & $(0.221)$ \\
\hline High Relative Consciousness (RC_Higher): $\varphi$ & $-0.2923^{* *}$ & $-0.3599 * * *$ & $-0.3795 * * *$ & -0.1970 & -0.0299 & 0.0466 \\
\hline$R C \_H i g h e r(=1$, if $R C$ is higher and much higher $)$ & $(0.118)$ & $(0.089)$ & $(0.079)$ & $(0.161)$ & $(0.099)$ & $(0.091)$ \\
\hline Interaction Terms: $\theta$ & -0.0553 & 0.0526 & 0.0938 & $0.4522 * *$ & $0.4954 * *$ & $0.5032 *$ \\
\hline$L I R G \times R C \_$Higher & $(0.150)$ & $(0.178)$ & $(0.373)$ & $(0.189)$ & $(0.197)$ & $(0.274)$ \\
\hline \multicolumn{7}{|l|}{ Absolute Income } \\
\hline Log Household Income & $\begin{array}{l}0.3462 * * * \\
(0.050)\end{array}$ & $\begin{array}{l}0.3483 * * * \\
(0.058)\end{array}$ & $\begin{array}{l}0.4384 * * * \\
(0.052)\end{array}$ & $\begin{array}{l}0.2228 * * * \\
(0.053)\end{array}$ & $\begin{array}{l}0.2393 * * * \\
(0.057)\end{array}$ & $\begin{array}{l}0.2729 * * * \\
(0.054)\end{array}$ \\
\hline \multicolumn{7}{|l|}{ Observations } \\
\hline & 2,880 & 2,691 & 2,775 & 2,484 & 2,440 & 2,454 \\
\hline
\end{tabular}

NOTES: Individual demographic and labor-related variables (which are used in Table 6) are all controlled for. RI1 indicates "Living Standard Comparison";

$\mathrm{RI} 2$ is "Social Comparison Income"; RI3 is "Aspiration Comparison Income". Standard errors in parentheses $* * * \mathrm{p}<0.01, * * \mathrm{p}<0.05, * \mathrm{p}<0.1$ 
Table 8. Individual Choice and Relative Income

\begin{tabular}{|c|c|c|c|c|c|c|}
\hline $\bar{Y}=$ Individual Choice of Living Environment (1 5) & Japan & & & The U.S. & & \\
\hline (5: Other's income is much higher) & $(1)$ & (2) & (3) & $(1)$ & (2) & (3) \\
\hline Relative Income & & & & & & \\
\hline $\begin{array}{l}\text { Living Standard Comparison } \\
\text { (5: Theirs is much higher than mine) }\end{array}$ & $\begin{array}{l}-0.0009 \\
(0.018)\end{array}$ & & & $\begin{array}{l}0.0505^{* * *} \\
(0.017)\end{array}$ & & \\
\hline $\begin{array}{l}\text { Social Comparison Income } \\
\text { (Income of People Around You) }\end{array}$ & & $\begin{array}{l}0.0687 * * \\
(0.029)\end{array}$ & & & $\begin{array}{l}0.0687 * * * \\
(0.021)\end{array}$ & \\
\hline $\begin{array}{l}\text { Aspiration Comparison Income } \\
\text { (One's Own Ideal Income) }\end{array}$ & & & $\begin{array}{l}0.0798 * * * \\
(0.024)\end{array}$ & & & $\begin{array}{l}0.0025 \\
(0.020)\end{array}$ \\
\hline Relative Consciousness & $-0.0349 * * *$ & $-0.0286 * * *$ & $-0.0293 * * *$ & -0.0070 & -0.0052 & -0.0051 \\
\hline Being consious of others' living standard (1 5) & $(0.012)$ & $(0.011)$ & $(0.011)$ & $(0.012)$ & $(0.011)$ & $(0.011)$ \\
\hline Absolute Income & $0.0389 * *$ & $0.0391 * *$ & 0.0247 & 0.0169 & -0.0021 & 0.0118 \\
\hline Log Income & $(0.017)$ & $(0.019)$ & $(0.019)$ & $(0.016)$ & $(0.017)$ & $(0.018)$ \\
\hline Observations & 2,146 & 1,954 & 1,990 & 1,942 & 1,893 & 1,891 \\
\hline R-Squared & 0.023 & 0.028 & 0.030 & 0.030 & 0.032 & 0.025 \\
\hline
\end{tabular}

NOTES: Individual demographic and labor-related variables (which are used in Table 6) are all controlled for.

Standard errors in parentheses $* * * \mathrm{p}<0.01,{ }^{* *} \mathrm{p}<0.05,{ }^{*} \mathrm{p}<0.1$ 
Table 9. Individual Choice and Relative Consciousness in association with Relative Income

\begin{tabular}{|c|c|c|c|c|}
\hline \multirow[t]{2}{*}{$\mathrm{Y}=$ Individual Choice of Living Environment (1 5) } & \multicolumn{2}{|l|}{ Japan } & \multicolumn{2}{|l|}{ The U.S. } \\
\hline & $(1)$ & $(2)$ & $(3)$ & $(4)$ \\
\hline & Whole & Restricted & Whole & Restricted \\
\hline \multicolumn{5}{|l|}{ Relative Variables } \\
\hline High Income Reference Group (HIRG): $\delta$ & $0.0634 * *$ & $0.0746^{*}$ & $0.1849 * * *$ & $0.2253 * * *$ \\
\hline Equals 1 if others' living standards are high(er) & $(0.029)$ & $(0.041)$ & $(0.047)$ & $(0.069)$ \\
\hline High Relative Consciousness (RC_Higher): $\varphi$ & -0.0178 & 0.0137 & 0.0190 & 0.0084 \\
\hline$R C \_H i g h e r(=1$, if $R C$ is higher or much higher $)$ & $(0.034)$ & $(0.047)$ & $(0.029)$ & $(0.039)$ \\
\hline Interaction Terms: $\theta$ & $-0.1145 * *$ & $-0.2166^{* * *}$ & $-0.1185^{* *}$ & $-0.1422 *$ \\
\hline HIRG $\times$ RC_Higher & $(0.054)$ & $(0.082)$ & $(0.058)$ & $(0.083)$ \\
\hline Absolute Income & $0.0430 * *$ & 0.0147 & 0.0171 & 0.0321 \\
\hline Log Own Income & $(0.017)$ & $(0.024)$ & $(0.016)$ & $(0.023)$ \\
\hline Observations & 2,146 & 1,045 & 1,942 & 1,000 \\
\hline R-Squared & 0.024 & 0.033 & 0.035 & 0.043 \\
\hline
\end{tabular}

NOTES: Individual demographic and labor-related variables (which are used in Table 6) are all controlled for.

Standard errors in parentheses $* * * \mathrm{p}<0.01, * * \mathrm{p}<0.05, * \mathrm{p}<0.1$ 


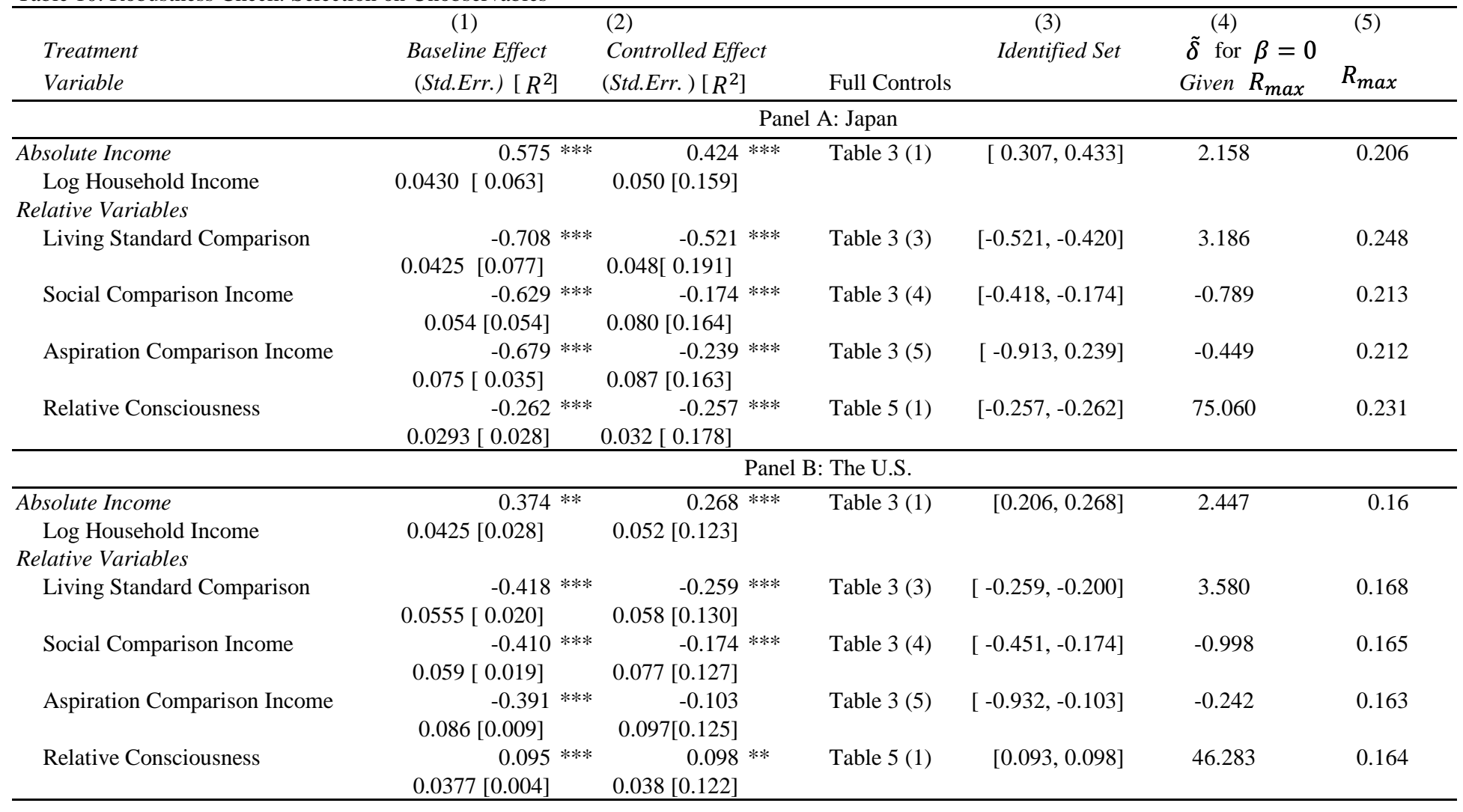

NOTES: This table shows the validation results for the analysis of the impact of household income at both absolute and relative terms on happiness.

Baseline effects of both Panel A and B include only gender and age. Full controls are socio-economic variables and labor-related variables included in Table 4. The identified set in Column (3) of this table is bounded below by $\tilde{\beta}$ and above by $\beta *$ calculated based on Rmax given in the last Column (5) and $\tilde{\delta}=1$. Column (4) shows the value of $\tilde{\delta}$ which would produce $\beta=0$ given the values of Rmax reported in the Column (5). * significant at $10 \%$ level, ** significant at $5 \%$ level, $* * *$ significant at $1 \%$ level 
Table A. Determinants of the Degree of Happiness

\begin{tabular}{|c|c|c|c|c|c|c|c|c|}
\hline \multirow[t]{2}{*}{ Y: Degree of Happiness $(0 \sim 10)$} & \multicolumn{4}{|l|}{ Japan } & \multicolumn{4}{|l|}{ The U.S. } \\
\hline & $\begin{array}{l}\text { Whole } \\
\text { (O-Logit) }\end{array}$ & $\begin{array}{l}\text { Whole } \\
\text { (OLS) }\end{array}$ & $\begin{array}{l}\text { Male } \\
(\mathrm{OLS})\end{array}$ & $\begin{array}{l}\text { Female } \\
(\text { OLS })\end{array}$ & $\begin{array}{l}\text { Whole } \\
\text { (O-Logit) }\end{array}$ & $\begin{array}{l}\text { Whole } \\
\text { (OLS) }\end{array}$ & $\begin{array}{l}\text { Male } \\
(\text { OLS })\end{array}$ & $\begin{array}{l}\text { Female } \\
(\text { OLS })\end{array}$ \\
\hline \multicolumn{9}{|l|}{ Main Control Variable } \\
\hline Log Household Income & $\begin{array}{l}0.4623 * * * \\
(0.053)\end{array}$ & $\begin{array}{l}0.4243 * * * \\
(0.050)\end{array}$ & $\begin{array}{l}0.4691 * * * \\
(0.077)\end{array}$ & $\begin{array}{l}0.4275 * * * \\
(0.066)\end{array}$ & $\begin{array}{l}0.2392 * * * \\
(0.046)\end{array}$ & $\begin{array}{l}0.2680 * * * \\
(0.052)\end{array}$ & $\begin{array}{l}0.2334 * * * \\
(0.074)\end{array}$ & $\begin{array}{l}0.3047 * * * \\
(0.074)\end{array}$ \\
\hline \multicolumn{9}{|l|}{ Demographic Variables } \\
\hline Female $(=1)$ & $\begin{array}{l}0.2565 * * * \\
(0.081)\end{array}$ & $\begin{array}{l}0.2106 * * * \\
(0.076)\end{array}$ & & & $\begin{array}{l}0.1038 \\
(0.073)\end{array}$ & $\begin{array}{l}0.1014 \\
(0.085)\end{array}$ & & \\
\hline Age & $\begin{array}{l}-0.0370 \\
(0.023)\end{array}$ & $\begin{array}{l}-0.0367 * \\
(0.022)\end{array}$ & $\begin{array}{l}-0.0548 * \\
(0.032)\end{array}$ & $\begin{array}{l}-0.0094 \\
(0.031)\end{array}$ & $\begin{array}{l}-0.0515 * * * \\
(0.013)\end{array}$ & $\begin{array}{l}-0.0600 * * * \\
(0.015)\end{array}$ & $\begin{array}{l}-0.0455^{* *} \\
(0.021)\end{array}$ & $\begin{array}{l}-0.0718 * * * \\
(0.022)\end{array}$ \\
\hline Age squared & $\begin{array}{l}0.0002 \\
(0.000)\end{array}$ & $\begin{array}{l}0.0002 \\
(0.000)\end{array}$ & $\begin{array}{l}0.0004 \\
(0.000)\end{array}$ & $\begin{array}{l}-0.0000 \\
(0.000)\end{array}$ & $\begin{array}{l}0.0005 * * * \\
(0.000)\end{array}$ & $\begin{array}{l}0.0006 * * * \\
(0.000)\end{array}$ & $\begin{array}{l}0.0004 * \\
(0.000)\end{array}$ & $\begin{array}{l}0.0007 * * * \\
(0.000)\end{array}$ \\
\hline High school graduates & $\begin{array}{l}0.3509 * * * \\
(0.103)\end{array}$ & $\begin{array}{l}0.3698 * * * \\
(0.098)\end{array}$ & $\begin{array}{l}0.4495 * * \\
(0.201)\end{array}$ & $\begin{array}{l}0.3640 * * * \\
(0.115)\end{array}$ & $\begin{array}{l}-0.0017 \\
(0.112)\end{array}$ & $\begin{array}{l}-0.0347 \\
(0.132)\end{array}$ & $\begin{array}{l}0.1884 \\
(0.191)\end{array}$ & $\begin{array}{l}-0.2457 \\
(0.185)\end{array}$ \\
\hline University graduates & $\begin{array}{l}0.3301 * * * \\
(0.090)\end{array}$ & $\begin{array}{l}0.2982 * * * \\
(0.087)\end{array}$ & $\begin{array}{l}0.1285 \\
(0.109)\end{array}$ & $\begin{array}{l}0.4935 * * * \\
(0.146)\end{array}$ & $\begin{array}{l}0.0778 \\
(0.091)\end{array}$ & $\begin{array}{l}0.1274 \\
(0.108)\end{array}$ & $\begin{array}{l}0.1820 \\
(0.148)\end{array}$ & $\begin{array}{l}0.0552 \\
(0.159)\end{array}$ \\
\hline Graduate school & $\begin{array}{l}0.7988 * * * \\
(0.247)\end{array}$ & $\begin{array}{l}0.8556 * * * \\
(0.245)\end{array}$ & $\begin{array}{l}0.6005^{* *} \\
(0.271)\end{array}$ & $\begin{array}{l}1.5474^{* *} \\
(0.600)\end{array}$ & $\begin{array}{l}0.1798 \\
(0.117)\end{array}$ & $\begin{array}{l}0.1830 \\
(0.137)\end{array}$ & $\begin{array}{l}0.2090 \\
(0.184)\end{array}$ & $\begin{array}{l}0.1398 \\
(0.208)\end{array}$ \\
\hline Married (=1) & $\begin{array}{l}0.7414 * * * \\
(0.179)\end{array}$ & $\begin{array}{l}0.6599 * * * \\
(0.168)\end{array}$ & $\begin{array}{l}1.0221 * * * \\
(0.232)\end{array}$ & $\begin{array}{l}0.2104 \\
(0.249)\end{array}$ & $\begin{array}{l}0.5584 * * * \\
(0.168)\end{array}$ & $\begin{array}{l}0.5196 * * * \\
(0.195)\end{array}$ & $\begin{array}{l}0.4125 \\
(0.332)\end{array}$ & $\begin{array}{l}0.6381 * * \\
(0.255)\end{array}$ \\
\hline Divorced $(=1)$ & $\begin{array}{l}0.1087 \\
(0.240)\end{array}$ & $\begin{array}{l}0.0580 \\
(0.224)\end{array}$ & $\begin{array}{l}-0.3891 \\
(0.332)\end{array}$ & $\begin{array}{l}0.1204 \\
(0.313)\end{array}$ & $\begin{array}{l}0.0674 \\
(0.188)\end{array}$ & $\begin{array}{l}0.0665 \\
(0.220)\end{array}$ & $\begin{array}{l}0.0182 \\
(0.360)\end{array}$ & $\begin{array}{l}0.1000 \\
(0.294)\end{array}$ \\
\hline Widow $(=1)$ & $\begin{array}{l}0.4424 * \\
(0.249)\end{array}$ & $\begin{array}{l}0.3342 \\
(0.240)\end{array}$ & $\begin{array}{l}0.0013 \\
(0.429)\end{array}$ & $\begin{array}{l}0.0959 \\
(0.315)\end{array}$ & $\begin{array}{l}-0.0912 \\
(0.192)\end{array}$ & $\begin{array}{l}-0.1992 \\
(0.223)\end{array}$ & $\begin{array}{l}-0.5767 \\
(0.376)\end{array}$ & $\begin{array}{l}0.1020 \\
(0.287)\end{array}$ \\
\hline Having a child $(=1)$ & $\begin{array}{l}0.3660 * * \\
(0.149)\end{array}$ & $\begin{array}{l}0.3583^{* *} \\
(0.141)\end{array}$ & $\begin{array}{l}0.3255 \\
(0.199)\end{array}$ & $\begin{array}{l}0.3139 \\
(0.204)\end{array}$ & $\begin{array}{l}-0.0716 \\
(0.103)\end{array}$ & $\begin{array}{l}-0.0400 \\
(0.119)\end{array}$ & $\begin{array}{l}-0.1186 \\
(0.170)\end{array}$ & $\begin{array}{l}0.0484 \\
(0.169)\end{array}$ \\
\hline Number of Household & $\begin{array}{l}-0.0991 * * * \\
(0.026)\end{array}$ & $\begin{array}{l}-0.0900 * * * \\
(0.025)\end{array}$ & $\begin{array}{l}-0.0721 * * \\
(0.036)\end{array}$ & $\begin{array}{l}-0.1092 * * * \\
(0.035)\end{array}$ & $\begin{array}{l}-0.0719 * * \\
(0.031)\end{array}$ & $\begin{array}{l}-0.0737 * * \\
(0.036)\end{array}$ & $\begin{array}{l}-0.0580 \\
(0.051)\end{array}$ & $\begin{array}{l}-0.0758 \\
(0.051)\end{array}$ \\
\hline \multicolumn{9}{|l|}{ Individual Characteristics } \\
\hline Health Condition (1-5) & $\begin{array}{l}0.3357 * * * \\
(0.033)\end{array}$ & $\begin{array}{l}0.3196 * * * \\
(0.030)\end{array}$ & $\begin{array}{l}0.3048 * * * \\
(0.043)\end{array}$ & $\begin{array}{l}0.3164 * * * \\
(0.042)\end{array}$ & $\begin{array}{l}0.3220 * * * \\
(0.032)\end{array}$ & $\begin{array}{l}0.3169 * * * \\
(0.035)\end{array}$ & $\begin{array}{l}0.2824 * * * \\
(0.049)\end{array}$ & $\begin{array}{l}0.3535 * * * \\
(0.050)\end{array}$ \\
\hline Religious Devotion (1-5) & $\begin{array}{l}0.1645 * * * \\
(0.031)\end{array}$ & $\begin{array}{l}0.1537 * * * \\
(0.029)\end{array}$ & $\begin{array}{l}0.1286 \text { *** } \\
(0.045)\end{array}$ & $\begin{array}{l}0.1682 * * * \\
(0.039)\end{array}$ & $\begin{array}{l}0.2527 * * * \\
(0.028)\end{array}$ & $\begin{array}{l}0.2464 * * * \\
(0.032)\end{array}$ & $\begin{array}{l}0.2613 * * * \\
(0.044)\end{array}$ & $\begin{array}{l}0.2289 * * * \\
(0.047)\end{array}$ \\
\hline \multicolumn{9}{|l|}{ Labor-related Variables } \\
\hline Self-employed $(=1)$ & $\begin{array}{l}0.1188 \\
(0.119)\end{array}$ & $\begin{array}{l}0.1376 \\
(0.114)\end{array}$ & $\begin{array}{l}-0.0394 \\
(0.136)\end{array}$ & $\begin{array}{l}0.5376^{* * *} \\
(0.217)\end{array}$ & $\begin{array}{l}0.0167 \\
(0.155)\end{array}$ & $\begin{array}{l}-0.0098 \\
(0.182)\end{array}$ & $\begin{array}{l}0.0514 \\
(0.229)\end{array}$ & $\begin{array}{l}-0.0415 \\
(0.300)\end{array}$ \\
\hline Public Sector $(=1)$ & $\begin{array}{l}0.1182 \\
(0.143)\end{array}$ & $\begin{array}{l}0.1224 \\
(0.141)\end{array}$ & $\begin{array}{l}0.1036 \\
(0.172)\end{array}$ & $\begin{array}{l}0.0961 \\
(0.247)\end{array}$ & $\begin{array}{l}-0.0874 \\
(0.119)\end{array}$ & $\begin{array}{l}-0.0900 \\
(0.140)\end{array}$ & $\begin{array}{l}-0.0234 \\
(0.204)\end{array}$ & $\begin{array}{l}-0.1536 \\
(0.196)\end{array}$ \\
\hline Part time job $(=1)$ & $\begin{array}{l}-0.0666 \\
(0.120)\end{array}$ & $\begin{array}{l}-0.0690 \\
(0.114)\end{array}$ & $\begin{array}{l}0.1214 \\
(0.393)\end{array}$ & $\begin{array}{l}0.0407 \\
(0.127)\end{array}$ & $\begin{array}{l}0.0214 \\
(0.241)\end{array}$ & $\begin{array}{l}0.0504 \\
(0.283)\end{array}$ & $\begin{array}{l}0.3899 \\
(0.559)\end{array}$ & $\begin{array}{l}-0.1651 \\
(0.337)\end{array}$ \\
\hline Unemployed (=1) & $\begin{array}{l}0.5774 * \\
(0.338)\end{array}$ & $\begin{array}{l}0.5270 * \\
(0.293)\end{array}$ & $\begin{array}{l}0.2062 \\
(0.392)\end{array}$ & $\begin{array}{l}1.1487 * * \\
(0.448)\end{array}$ & $\begin{array}{l}-0.8687 * * * \\
(0.218)\end{array}$ & $\begin{array}{l}-1.0068 * * * \\
(0.255)\end{array}$ & $\begin{array}{l}-1.0211 * * * \\
(0.370)\end{array}$ & $\begin{array}{l}-0.9525^{* * * *} \\
(0.355)\end{array}$ \\
\hline Not labor force $(=1)$ & $\begin{array}{l}0.3009 * * * \\
(0.097)\end{array}$ & $\begin{array}{l}0.2918 * * * \\
(0.092)\end{array}$ & $\begin{array}{l}0.3721 * * \\
(0.173)\end{array}$ & $\begin{array}{l}0.3806 * * * \\
(0.115)\end{array}$ & $\begin{array}{l}0.2155^{* *} \\
(0.096)\end{array}$ & $\begin{array}{l}0.1976 * \\
(0.111)\end{array}$ & $\begin{array}{l}0.4023^{* *} \\
(0.165)\end{array}$ & $\begin{array}{l}0.0589 \\
(0.155)\end{array}$ \\
\hline $\begin{array}{l}\text { Have ever been unemployed } \\
\text { in the last } 5 \text { years }(=1)\end{array}$ & $\begin{array}{l}-0.2481 * * * \\
(0.092)\end{array}$ & $\begin{array}{l}-0.2581 * * * \\
(0.087)\end{array}$ & $\begin{array}{l}-0.2058^{*} \\
(0.125)\end{array}$ & $\begin{array}{l}-0.2608 * * \\
(0.121)\end{array}$ & $\begin{array}{l}-0.3355^{* * * *} \\
(0.091)\end{array}$ & $\begin{array}{l}-0.4114 * * * \\
(0.106)\end{array}$ & $\begin{array}{l}-0.6328 * * * \\
(0.149)\end{array}$ & $\begin{array}{l}-0.2000 \\
(0.152)\end{array}$ \\
\hline Observations & 2,894 & 2,894 & 1,415 & 1,479 & 2,502 & 2,502 & 1,249 & 1,253 \\
\hline R-Squared & & 0.159 & 0.184 & 0.159 & & 0.123 & 0.151 & 0.120 \\
\hline
\end{tabular}

NOTES: This appendix compares the results by estimation methods (Ordered logit and OLS). Also, it reports the estimation results by gender.

Standard errors in parentheses $* * * \mathrm{p}<0.01, * * \mathrm{p}<0.05, * \mathrm{p}<0.1$ 
Table B. Relative Consciousness and Relative Income by Reference Group

\begin{tabular}{|c|c|c|c|c|c|c|}
\hline & Japan & & & The U.S. & & \\
\hline Reference Group & Percent & $\begin{array}{r}\text { Relative } \\
\text { Consciousness }\end{array}$ & $\begin{array}{l}\text { Relative } \\
\text { Income }\end{array}$ & Percent & $\begin{array}{c}\text { Relative } \\
\text { Consciousness }\end{array}$ & $\begin{array}{l}\text { Relative } \\
\text { Income }\end{array}$ \\
\hline Neighbor & 49.73 & 2.64 & 0.12 & 51.04 & 3.66 & 0.20 \\
\hline Classmates of your school days & 6.88 & 2.79 & 0.15 & 3.17 & 3.81 & 0.45 \\
\hline Friend/Acquaintance & 3.56 & 2.71 & 0.18 & 7.15 & 3.58 & 0.16 \\
\hline Relatives & 3.59 & 2.96 & 0.06 & 6.74 & 3.78 & 0.20 \\
\hline Families of your children's classmates & 6.61 & 2.65 & 0.00 & 2.35 & 3.69 & 0.07 \\
\hline $\begin{array}{l}\text { Person at work in your company } \\
\text { (similar individual characteristics) }\end{array}$ & 4.18 & 2.67 & 0.09 & 3.81 & 3.74 & 0.11 \\
\hline Person at work in your company & 6.32 & 2.79 & 0.13 & 3.51 & 3.41 & 0.02 \\
\hline $\begin{array}{l}\text { Person working in another company } \\
\text { (same buz/similar individual characteristics) }\end{array}$ & 1.07 & 2.73 & 0.26 & 1.09 & 3.56 & 0.11 \\
\hline $\begin{array}{l}\text { Person working in another company } \\
\text { in the same business }\end{array}$ & 1.82 & 2.66 & 0.18 & 0.65 & 3.57 & 0.22 \\
\hline Average people in Japan / in the US & 11.96 & 2.33 & 0.11 & 16.55 & 3.62 & 0.36 \\
\hline Average people in the world & 0.16 & 2.96 & 0.26 & 1.5 & 3.61 & 0.22 \\
\hline Others & 0.67 & 2.65 & 0.38 & 2.45 & 3.56 & 0.26 \\
\hline Don't Know & 3.45 & 2.34 & 0.30 & N/A & N/A & N/A \\
\hline \multicolumn{7}{|l|}{$\overline{R e \text {-categorized Reference Group }}$} \\
\hline Neighbor & 49.73 & 2.64 & 0.12 & 51.04 & 3.66 & 0.20 \\
\hline Family & 10.44 & 2.88 & 0.10 & 10.32 & 3.63 & 0.17 \\
\hline Friend/Acquaintance & 10.2 & 2.85 & 0.19 & 9.09 & 3.67 & 0.29 \\
\hline Colleagues & 13.39 & 2.68 & 0.09 & 9.06 & 3.67 & 0.08 \\
\hline Average & 12.12 & 2.65 & 0.18 & 18.05 & 3.57 & 0.24 \\
\hline
\end{tabular}

NOTES: Respondents were asked to whom they compared themselves when they were asked their relative status in terms of living standard (income). In Japan, there was one more choice of "don't know". We recategorized the reference group into five in the bottom for an easier comparsion. The mean values of relative consciousness and relative income, which is calculated by $\ln \left(Y_{R_{i}}^{j} / Y_{i}\right)$ are reported in the following columns 
Table C. Happiness and Relative Income (Income difference)

\begin{tabular}{|c|c|c|c|c|c|c|c|c|}
\hline \multirow[t]{2}{*}{ Y: Degree of Happiness (0 10) } & \multicolumn{4}{|l|}{ Japan } & \multicolumn{4}{|l|}{ The U.S. } \\
\hline & $(1)$ & $(2)$ & (3) & $(4)$ & $(1)$ & $(2)$ & (3) & $(4)$ \\
\hline \multicolumn{9}{|l|}{ Absolute Income } \\
\hline Log Household Income & $\begin{array}{l}0.4243 * * * \\
(0.050)\end{array}$ & $\begin{array}{l}0.2998 * * * \\
(0.050)\end{array}$ & $\begin{array}{l}0.2969 * * * \\
(0.061)\end{array}$ & $\begin{array}{l}0.3769 * * * \\
(0.052)\end{array}$ & $\begin{array}{l}0.2680 * * * \\
(0.052)\end{array}$ & $\begin{array}{l}0.2246 * * * \\
(0.053)\end{array}$ & $\begin{array}{l}0.2106 * * * \\
(0.057)\end{array}$ & $\begin{array}{l}0.2557 * * * \\
(0.055)\end{array}$ \\
\hline \multicolumn{9}{|l|}{ Relative Income } \\
\hline $\begin{array}{l}\text { Living Standard Comparison } \\
\text { (5: Theirs is much higher than mine) }\end{array}$ & & $\begin{array}{l}-0.5214 * * * \\
(0.048)\end{array}$ & & & & $\begin{array}{l}-0.2592 * * * \\
(0.058)\end{array}$ & & \\
\hline $\begin{array}{l}\text { Social Comparison Income } \\
\text { (Income of People Around You - One's Own Actual }\end{array}$ & Income) & & $\begin{array}{l}-0.4629 * * * \\
(0.114)\end{array}$ & & & & $\begin{array}{l}-0.3464 * * \\
(0.138)\end{array}$ & \\
\hline $\begin{array}{l}\text { Aspirational Income Comparison } \\
\text { (One's Own Ideal Income - One's Own Actual Incom }\end{array}$ & & & & $\begin{array}{l}-0.6261 * * * \\
(0.147)\end{array}$ & & & & $\begin{array}{l}-0.1739 \\
(0.221)\end{array}$ \\
\hline Observations & 2,894 & 2,883 & 2,692 & 2,778 & 2,502 & 2,497 & 2,452 & 2,466 \\
\hline R-Squared & 0.159 & 0.191 & 0.168 & 0.166 & 0.123 & 0.129 & 0.126 & 0.125 \\
\hline
\end{tabular}

NOTES: For a more explicit interpretation of the coefficients regarding relative income, we created an indicator of $Y_{R_{i}}^{j}-Y_{i}$ as a proxy for relative income. A positive value indicates that household income of the comparison group or one's own aspirational income is higher than actual household income. The unit is 10,000 USD (1 million JPY). Standard errors in parentheses $* * * \mathrm{p}<0.01, * * \mathrm{p}<0.05, * \mathrm{p}<0.1$ 